\title{
Turning Themselves In: Why Companies Disclose Regulatory Violations
}

\author{
Jodi L. Short ${ }^{*}$ \\ Department of Sociology \\ University of California, Berkeley \\ jodishort@earthlink.net \\ Michael W. Toffel \\ Haas School of Business \\ University of California, Berkeley \\ toffel@haas.berkeley.edu
}

Version: July 13, 2005

\begin{abstract}
As part of a recent trend toward more cooperative relations between regulators and industry, novel government programs are encouraging firms to monitor their own regulatory compliance and voluntarily report their own violations. In this study, we examine how enforcement activities, statutory protections, community pressure, and organizational characteristics influence organizations' decisions to self-police. We created a comprehensive dataset for the "Audit Policy", a United States Environmental Protection Agency program that encourages companies to selfdisclose violations of environmental laws and regulations in exchange for reduced sanctions. We find that facilities were more likely to self-disclose if they were recently inspected or subjected to an enforcement action, were narrowly targeted for heightened scrutiny by a US EPA initiative, and were larger and thus more prominent in their environment. While we find some evidence that state-level statutory immunity facilitates self-disclosure, we find no evidence that statutory audit privilege does so.
\end{abstract}

The pitched political battles over regulation in the 1970s and 1980s, from deregulation to Reagan's vow to get government “off the backs” of industry, have given way in recent years to a new

\footnotetext{
${ }^{*}$ Corresponding author. Insightful comments by Neil Fligstein, Robert Kagan, David I. Levine, Howard Shelanski, and Jason Snyder are gratefully acknowledged, as is research funding from the Center for Responsible Business and the Institute of Business and Economic Research at the Haas School of Business. Ara Abrahamian provided excellent research assistance.
} 
wave of voluntary self-regulation programs based on a more cooperative approach between government and industry. Regulatory agencies are embracing programs that see firms as active participants in their own governance. And from the industry side, talk is increasingly about companies regulating themselves rather than trying to avoid regulation altogether. Industry proponents argue that self-regulation is a more efficient and effective way to achieve regulatory goals and that voluntary, private compliance initiatives should largely replace what they see as a cumbersome, bureaucratic and outdated “command-and-control” regulatory system (Orts 1995, Murray 1999). They are supported by a substantial and growing body of academic literature touting the virtues of a more cooperative regulatory system (Bardach \& Kagan 1982; Scholz 1984; Ayres \& Braithwaite 1992; Gunningham \& Grabowsky 1998). More importantly, this cooperative approach has influenced the practices of regulatory agencies, resulting in the proliferation of voluntary selfregulation programs that engage firms as partners in regulatory activities, from achieving "beyond compliance” results to policing their own noncompliance.

A regulatory system that relies increasingly on corporate self-regulation ultimately can be effective only if organizations are willing to admit and correct their failures as well as tout their successes. To this end, several regulatory agencies have developed "self-policing” programs that provide incentives to encourage companies to self-disclose their legal violations, shifting the burden of monitoring regulatory compliance from the government to the private sector. For example, through its Hazard Analysis and Critical Control Point program, the US Department of Agriculture recently reduced the number of onsite inspectors at slaughterhouses and "shifted much of the responsibility for safety to the plants, requiring them to identify vulnerable points in their production lines and build in steps to kill germs” (Peterson \& Drew 2003:A1). ${ }^{1}$

\footnotetext{
${ }^{1}$ In addition, the US Department of Justice Corporate Leniency Program encourages companies to disclose illegal anti-competitive activity by offering amnesty, an approach many other nations have since replicated (Medinger 2003). The US Department of Defense established a self-disclosure program to reduce fraud among government contractors by offering limited liability, maximum confidentiality allowed by law, and other benefits to firms that
} 
These types of initiatives carry promise as well as pitfalls. On the one hand, the incentives of self-policing programs have encouraged many companies to report and correct problems that regulators never would have discovered, suggesting the possibility for real improvements in compliance. On the other hand, without any evidence that they improve compliance, such programs may give industry an unprecedented and unwarranted level of control over its own regulation, raising "fears of the 'fox guarding the henhouse"” (Cox 2004:28). Such programs risk undermining compliance by publicly praising participants who may be hiding egregious violations behind their self-disclosure of relatively minor infractions (Pfaff \& Sanchirico 2004). In addition, by providing the regulated community with broad discretion to determine the scope of regulatory enforcement and to define the meaning and content of a violation, self-policing programs may subtly alter what it means to comply and even how regulators define success for the agency.

Until now, the debate over corporate self-regulation has been waged largely in terms of policy and ideology. We are skeptical of the competing claims this debate has produced: namely, that corporate self-regulation is mere "greenwashing" or, on the other hand, that it can supplant the role of government in overseeing industrial activities. In this study, we argue that cooperative strategies and market-based solutions may effectively complement, but cannot substitute for, more coercive approaches to regulatory enforcement.

Among the first empirical studies to address self-policing behavior, this article seeks to understand what influences organizations to police their own operations and "turn themselves in" by self-disclosing their regulatory compliance infractions. We use longitudinal cross-sectional data on voluntary disclosures under the United States Environmental Protection Agency (US EPA) Audit Policy, which provides rich data on how firms actually behave when they know they have violated the law.

self-disclose procurement violations (Fleder 1999). Similarly, the Securities and Exchange Commission encourages self-disclosure by informally offering prosecutorial leniency (Duggin 2003). 
We find that despite the rhetoric of cooperation surrounding self-policing programs, they work best when coupled with coercive regulatory measures such as inspections and enforcement actions. Facilities were more likely to self-disclose violations if they were recently inspected or subjected to an enforcement action, were narrowly targeted for heightened scrutiny by a US EPA initiative, and were more prominent in their community as indicated by having more employees or revenues.

The paper proceeds as follows. In the next section, we review the literature on compliance and self-policing. In Section 2, we describe the US EPA Audit Policy, the empirical setting of our research. In Section 3, we hypothesize how various institutional pressures, organizational characteristics, and legal institutions may influence facilities' decisions whether to self-police. Section 4 describes our sample and measures, and Section 5 details our empirical methods and presents our results. Finally, we discuss our results in Section 6, including conclusions and suggestions for future research.

\section{LITERATURE REVIEW}

There is a small but growing literature on corporate self-regulation, consisting primarily of studies that either evaluate "beyond compliance" initiatives or model self-policing behavior. In the arena of environmental protection, for example, both government and industry have established programs that recognize and reward firms for environmental performance and management practices that go above and beyond what the law requires. ${ }^{2}$ Evaluations of these "beyond compliance" programs, however, have found little to support the political enthusiasm for them. There is little evidence that these programs have attracted superior performers or have led to improved performance (King \& Lenox 2000; Welch, Mazur \& Bretschneider 2000; Lenox \& Nash 2003;

\footnotetext{
${ }^{2}$ Examples include government partnership programs such as the United States Environmental Protection Agency's (US EPA) Greenlights and 33/50 programs and the United States Department of Energy's Climate Challenge Program, negotiated agreements between regulators and industry such as Germany's Global Warming Prevention program and the Netherlands' Declaration on the Implementation of Environmental Policy, and fully private-sector initiatives such as the chemical industry's Responsible Care, the ski industry's Sustainable Slopes, and the Hotel Green Leaf Eco-Rating Program.
} 
Rivera \& de Leon 2004), prompting some to charge that they are nothing more than industry “greenwashing” (Eden 1996). ${ }^{3}$

Much less is known about self-policing programs, largely due to the difficulty of observing firms’ internal monitoring and policing decisions. The extant literature focuses on economic models of self-policing behavior, touting it as a way to reduce government monitoring and enforcement costs (Kaplow \& Shavell 1994), optimize levels of self-auditing by firms (Pfaff \& Sanchirico 2000), and reduce firms’ costs of avoiding detection (Innes 2001). Our data on actual firm self-disclosures will provide a valuable empirical dimension to this literature.

To develop hypotheses about why firms turn themselves in when they have broken the law, we look to the related literature on why they comply in the first place. A significant body of research examines what factors influence compliance with legal obligations. The most common conceptualization of compliance behavior comes out of deterrence theory, an economic model in which firms are rational, “amoral calculators” (Kagan \& Scholz 1984) that will comply with legal directives only to the extent that the costs of expected penalties exceed the benefits of noncompliance. According to deterrence theory, firms' compliance behavior is influenced both by specific deterrence -- "the fear engendered by the prior experience of being inspected, warned or penalized themselves” (Thornton, Gunningham \& Kagan 2005:263) - and by general deterrence, or "hearing about legal sanctions against others” (Thornton, Gunningham \& Kagan 2005:263, Gibbs 1986). The deterrent effect of potential sanctions is often viewed as a function of both their likelihood and severity (e.g., Friedman 1975).

This rational choice perspective dominates the theoretical literature about self-policing, which is largely comprised of economic models that seek to determine optimal outcomes (e.g., Pfaff and Sanchirico 2000; Innes 2001) as well as legal and policy arguments supporting or

\footnotetext{
${ }^{3}$ For exceptions, see Khanna \& Damon (1999) and Toffel (2005).
} 
denouncing self-regulation based on normative concerns (e.g., Kesan 2000; Murray 1999; Geltman \& Mathews 1997; Goldsmith \& King 1997; Grayson \& Landgraf 1997; Hunt \& Wilkins 1992). The central premise of this literature is that firms will self-disclose only when it is in their economic self-interest to do so, based on a strict cost-benefit model of firm decisionmaking that assesses whether the costs of self-reporting are less than the expected costs of attempting to hide a violation.

While the deterrence-based approach to compliance captures important dynamics involved in self-regulation and continues to dominate academic literature and regulatory practice, a significant body of research suggests that compliance is more normatively-based. Several recent studies have found that individuals and organizations alike comply with law not out of fear, but out of a sense of duty or a desire to do the right thing (May 2004; Gunningham et al. 2004). Vandenbergh (2003), for instance, cites evidence that compliance with environmental law is motivated by a duty to follow the law and to avoid endangering human health. In addition, several studies have shown a strong link between legitimacy and compliance, with people more willing to follow the directives of an authority they see as legitimate (Tyler 1990), and organizations seeking legitimacy through public displays of legal compliance (Meyer and Rowan 1977).

A growing body of socio-legal research suggests that compliance behavior is best explained by a complex combination of deterrence instruments as well as social and moral considerations that shape cost-benefit calculations about the risks of non-compliance. Kagan, Gunningham \& Thornton (2003), for instance, argue that firms must comply not only with the formal legal requirements of their regulatory license, but also with the "social license” granted by their local communities -- all within the context of their particular economic constraints. Thus, they show how many firms "overcomply" with environmental regulations to maintain a good reputation within their local community. 
This body of work suggests that the neo-classical economic basis of the deterrence model overlooks potentially important differences in how firms perceive and assess their options to maximize profits as well as distinct, normatively-based motivations for compliance. Some scholars have looked to new institutional theories of organizations, which emphasize the symbiotic relationship of organizations and their environments, to understand what other factors might influence compliance decision-making. From this perspective, law and regulation provide not only a coercive set of incentives, but a normative framework within which firms measure their reputation and legitimacy, and a cognitive framework that constitutes what is possible and desirable within a given environment (DiMaggio \& Powell 1991, Edelman \& Suchman 1997). In this conception, firmlevel cost-benefit calculations are embedded in the complex interaction of economic demands with broader factors like law, culture, and norms, and we draw on these insights to develop our hypotheses.

New institutional research suggests that when internal corporate compliance mechanisms are sufficiently institutionalized, they generate their own commitments and justifications that can induce compliance despite decreased regulatory enforcement (Dobbin \& Sutton 1998, Edelman et al. 1999). In fact, some scholars have argued that sufficiently institutionalized compliance measures would allow industry to regulate itself without the threat of government sanctions (King \& Lenox 2000; Gunningham 1995; Rees 1994). For instance, Rees (1994) argues that, following the accident at Three Mile Island, the nuclear power industry built a successful regime of self-regulation that has institutionalized a sense of communal responsibility among firms and produced significant safety improvements. He defends the industry's independence from government regulators and its ability to enforce standards through peer pressure and a shared set of industry norms. It is not clear, however, how generalizable his insights are outside this small, highly specialized and catastrophically dangerous industry that was fighting for its survival following a major accident. As noted above, studies of other voluntary "beyond compliance" initiatives have found much more limited success 
(King \& Lenox 2000; Welch, Mazur \& Bretschneider 2000; Lenox \& Nash 2003; Rivera \& de Leon 2004). And many researchers suggest that voluntary self-regulation may only be effective when supplemented by third party oversight and the threat of sanctions (King \& Lenox 2000; Lenox \& Nash 2003; Rivera \& de Leon 2004). Our analysis examines how coercive enforcement mechanisms like sanctions and inspections interact with benefits and incentives to produce desired regulatory outcomes.

Our research expands on the prior literature in three important ways. First, we apply insights from the compliance/deterrence literature in a novel setting to predict not whether firms will comply with law, but whether they will come clean when they have failed to comply. Our data provide a unique window on how firms behave when they know they have violated the law, thus allowing us to observe behavior that has thus far largely been studied in the compliance literature only theoretically

(May 2004; Thornton, Gunningham \& Kagan 2005) or experimentally (Paternoster \& Simpson 1996). Second, while we rely on the rational-choice perspective of deterrence theory to develop many of our hypotheses about self-reporting behavior, we attempt to integrate it with a much broader array of legal, political and cultural factors than recognized in previous studies of self-policing. We draw on institutional theory to develop a more nuanced approach that acknowledges managers' costbenefit calculations are embedded in and influenced by the broader institutional environment. Finally, by showing how traditional deterrence strategies as well as broader institutional factors influence self-policing practices, we hope to invigorate debate in the self-regulation literature, which tends to ignore the influence of both government and social context.

\section{THE US EPA AUDIT POLICY}

The US EPA's “Incentives for Self-Policing: Discovery, Correction and Prevention of Violations” (Audit Policy), launched in 1995, provides the empirical setting for our research. This program provides incentives for companies to identify, voluntarily report, and correct environmental violations. In exchange, US EPA promises to reduce or waive penalties that would be owed 
otherwise and provides a loose assurance that it will not refer voluntarily reported cases to the US Department of Justice (US DOJ) for criminal prosecution. The main objective of the Audit Policy is to encourage facilities to implement "systematic, objective, and periodic" environmental auditing and to develop “documented, systematic procedure[s] or practice[s] which reflects the regulated entity's due diligence in preventing, detecting, and correcting violations” (Federal Register 1995:66708). ${ }^{4}$ US EPA waives $75-100 \%$ of the gravity-based (punitive) penalties ${ }^{5}$ associated with self-disclosed violations, depending on whether they meet all of the Audit Policy's requirements. ${ }^{6}$ In addition, US EPA assures self-disclosers that the agency will not routinely request or use environmental audit reports as a part of routine inspections or to initiate civil or criminal investigations; ${ }^{7}$ nor will it refer self-reported violations to US DOJ for criminal prosecution except in rare circumstances. ${ }^{8}$

The Audit Policy has been widely used since its adoption. According to a dataset we constructed based on US EPA databases and documents (described below), nearly 3500 facilities

\footnotetext{
${ }^{4}$ Facilities must promptly disclose the violation to US EPA, correct the violation, and take steps to prevent future violations. The Audit Policy does not apply to violations that "resulted in serious actual harm or which may have presented an imminent and substantial endangerment to public health or the environment” (Federal Register 1995: 66709), or to violations that are similar to others the facility experienced within the past several years. Disclosures under the Audit Policy cannot result from any regulatory or permit requirements, enforcement actions, employee whistleblowers, or third party discovery. .

${ }^{5}$ The US EPA (2004) notes, "In general, civil penalties that EPA assesses are comprised of two elements: the economic benefit component and the gravity-based component. The economic benefit component reflects the economic gain derived from a violator's illegal competitive advantage. Gravity-based penalties are that portion of the penalty over and above the economic benefit. They reflect the egregiousness of the violator's behavior and constitute the punitive portion of the penalty."

${ }^{6}$ For self-reporters who meet all of the Audit Policy's conditions, US EPA waives $100 \%$ of gravity-based penalties. When violations are discovered by means other than environmental audits or due diligence efforts but all other conditions are met, $75 \%$ of gravity-based penalties are waived. However, US EPA retains full discretion under the Audit Policy to recover any economic benefit the self-reporter gained as a result of noncompliance "to preserve a 'level playing field' in which violators do not gain a competitive advantage over regulated entities that do comply" (Federal Register 1995:66712). US EPA may also waive these penalties if it views the economic benefit to be insignificant.

${ }^{7}$ However, US EPA reserves the right to seek such reports if it has independent reason to believe that a violation has occurred, and federal law provides no audit privilege for their protection. Many commentators see these guidelines as insufficiently protective of confidentiality.

${ }^{8}$ US EPA will not refer self-reported violations for criminal prosecution so long as they do not involve a prevalent management philosophy or practice that concealed or condoned the violations or high-level official involvement in the violations. This aspect of the policy has been particularly controversial, because US EPA has wide discretion to determine whether a reported violation qualifies for this kind of relief. In addition, the criminal environmental enforcement arm of the US DOJ often has a different view on how cases should be treated and is not bound by US EPA's Audit Policy. Self-reporters thus place themselves at some degree of risk that they may face criminal charges from US DOJ.
} 
have disclosed violations during 1997 - 2003, and many of these facilities simultaneously disclosed involved multiple violations. Even though many self-reporters incurred significant costs to remedy the violations they voluntarily disclosed, the majority of participants held favorable views of the program (Federal Register 1999). US EPA also touts the program as a success: “Discovery and correction of violations under the policy have removed pollutants from the air and water, reduced health and environmental risks and improved public information on potential environmental hazards” and ensured safe management of PCBs and other hazardous wastes (Federal Register 1999:26745).

The Audit Policy explicitly excludes from its purview violations that result in "serious actual harm or substantial health risk.” Moreover, because this standard is ambiguous, firms may interpret it more broadly than it is meant to apply and thus avoid voluntarily reporting compliance violations involving emissions, effluent, or solid waste that results in little actual harm or heath risk. As a result, voluntarily reported violations tend to be less serious than EPA-discovered violations (Pfaff \& Sanchirico 2004). While it is important to acknowledge the Audit Policy’s limitations, it would be wrong to infer that the kinds of record-keeping and reporting violations typically disclosed under the Audit Policy are trivial. Emissions violations under all the major environmental permitting statutes can be discovered and prosecuted only if the regulated community takes seriously its paperwork obligations. Thus, while lawful recordkeeping and reporting are not themselves sufficient, they represent a necessary precondition to environmental compliance and to successful self-policing. As such, in its evaluation of the Audit Policy, US EPA noted "[The] discovery and correction of violations under the policy have removed pollutants from the air and water, reduced health and environmental risks and improved public information on potential environmental hazards” (Federal Register 1999:26745).

\section{WHO TURNS THEMSELVES IN?}

In this section, we describe several factors that encourage organizations to turn themselves in. We hypothesize that facilities will self-disclose compliance violations when they expect to incur 
more total costs for hiding the violation than for disclosing it, and argue that these costs include not only monetary penalties but also damage to the firm's reputation and relationships with local communities and regulators. We posit that such economic cost-benefit calculations are deeply influenced by institutional pressures exerted by regulators and local communities on the facility, the facility's sensitivity to these pressures, and the broader legal environment including the presence of legal protections for self-reporters (Edelman 1990:1406).

\subsection{THE REGULATORY ENVIRONMENT}

We first examine various legal and regulatory aspects that comprise the environment in which regulated facilities decide whether or not to turn themselves in. A facility's regulatory environment includes not only applicable regulations, but enforcement activities undertaken by regulators and legal protections and incentives designed to encourage self-reporting. We examine how government wields these regulatory tools in the context of voluntary programs and hypothesize how this influences regulated entities’ decision whether to self-police.

\subsubsection{Enforcement Activities: Specific Deterrence}

The level of regulatory enforcement is a crucial component of an organization's regulatory environment, informing a facility’s expectations about the likelihood of getting caught out of compliance and creating a framework of legal experience within which firms ascertain the risks and benefits of self-reporting. Regulatory enforcement policies typically include both specific and general deterrence strategies. ${ }^{9}$ Numerous studies have shown that specific deterrence measures such as regulatory inspections improve compliance at targeted firms (Gunningham, Thornton \& Kagan 2005, Helland 1998, Magat \& Viscusi 1990), because frequent inspections increase the likelihood that regulators will discover and penalize violations (Dimento 1989). In addition, since regulators

\footnotetext{
${ }^{9}$ As discussed earlier, "specific deterrence" is the deterrence effect of enforcement actions against a particular facility, whereas "general deterrence" is the deterrence effect of a facility's knowledge about enforcement actions against a category to which a facility belongs, such as an industry or geographic region.
} 
often target inspections toward facilities they believe are more likely to have violations (Harrington 1988), facilities facing more inspections (regardless of whether violations are discovered) may be more likely to self-report to bolster regulators’ confidence of their willingness to comply.

Facilities may expect that self-disclosing may credibly signal their commitment to compliance, so that inspectors can shift their attention to inspect other facilities where they are more likely to discover more violations. Facilities might also expect that regulators will "reward" selfdisclosers by inspecting them less often to encourage additional disclosures from them and to encourage other facilities to disclose. Indeed, despite the Audit Policy's formal stance that participation would not decrease inspections, US EPA has informally conceded that the Audit Policy can attract self-disclosures only if the agency is successful in avoiding any impression that selfdisclosing might lead to increased scrutiny. ${ }^{10}$ Consequently, facilities subjected to more frequent inspections will be more likely to self-disclose violations to avoid the costs of detection and to generate goodwill with suspicious regulators.

Inspections that uncover violations may have an even greater compliance impact. Because regulatory agencies are known to target worse violators with their limited inspection resources (US EPA 1992, Helland 1998), facilities found in violation can expect to be targeted for more frequent inspections in the near future (Helland 1998, Harrington 1988). Furthermore, inspections that uncover multiple violations suggest that the firm has a poor relationship with regulators - both because of their apparent unwillingness to comply and because high violation rates can result from dismayed inspectors legalistically interpreting regulations to maximize the number of violations (Aoki \& Coiffi 2000). Such firms may be particularly eager to use self-reports to show their good faith willingness to comply in an attempt to mitigate their heightened scrutiny (Helland 1998). Therefore, controlling for inspection rate, we expect organizations with more violations discovered

\footnotetext{
${ }^{10}$ In a conversation with one of the authors, a US EPA program administrator noted, "The Agency has to avoid the perception that it is picking on companies who participate in the Audit Policy.” (March 16, 2004).
} 
by inspectors are more likely to self-report regulatory compliance violations.

Growing empirical evidence suggests that penalties and enforcement actions also improve facilities’ regulatory compliance (Gunningham, Thornton \& Kagan 2005; Gray \& Shadbegian 2005; Mendelhoff \& Gray 2005; Gray \& Scholz 1991; Aoki \& Coiffi 2000). Enforcement actions are administrative or judicial proceedings that subject firms to fines, penalties and various forms of injunctive relief, and they represent more serious compliance problems than merely cited violations. Firms with poor compliance records may tend to go the extra mile to demonstrate compliance for several reasons. First, their experience may make them more sensitive to the costs of noncompliance, especially since they may face escalating consequences for future violations as "repeat offenders.” For this reason, they may wish to put themselves back into the good graces of the regulator (Scholz 1984, Pfaff \& Sanchirico 2000, Helland 1998). In addition to considerations emanating from a facility's cost function, “enforcement actions serve to focus attention on organizational patterns of behavior that may be out of line with organizational beliefs and accepted social norms” (Gray \& Scholz 1993:200). As such, we predict that facilities with recent enforcement actions will be particularly motivated to self-disclose violations.

\subsubsection{Enforcement Activities: General Deterrence}

Beyond their own individual experience, facilities are also influenced by enforcement activities that affect other organizations in the broader regulatory community. For example, the overall stringency of an inspection regime can influence companies’ expectations that regulators will detect their violations (Cohen 1987; Cohen 2000; Epple \& Visscher 1984). In addition, high profile enforcement actions against other firms have motivated some companies to review their compliance programs, and to modify their equipment, monitoring practices, and employee training (Thornton, Gunningham \& Kagan 2005).

Some regulators have attempted to leverage general deterrence by launching targeted 
enforcement initiatives that single out particular industries for added scrutiny (Epple \& Visscher 1984, Cohen 1987, Anderson \& Talley 1995, Ross 1982). Such efforts attempt to increase facilities’ expectations that their violations will be discovered, thereby motivating greater compliance. For example, US EPA has launched enforcement initiatives to encourage compliance and self-auditing within sectors such as steel mini-mills and chemical manufacturers. In addition, US EPA releases a list of "National Priority" sectors where it will target enforcement resources. Such campaigns are designed to encourage compliance by increasing these targeted facilities’ perceived likelihood of getting caught. ${ }^{11}$ Similarly, we expect that this heightened expectation of getting caught will encourage organizations facing general deterrence initiatives to self-disclose violations.

\subsubsection{Statutory Protections}

State law is an integral part of the regulatory environment facing facilities as they decide whether to report compliance infractions, with some states providing much greater protection for corporate disclosures than others. To encourage self-reporting, states have developed two types of legal protection for voluntary disclosers: (1) audit privilege laws that prevent state regulatory agencies and private parties from obtaining any documents produced in connection with an internal environmental audit or using them in court against a voluntary discloser; and (2) immunity statutes that shield self-reporters from prosecution for violations they voluntarily report. States have taken a variety of approaches, with some providing one or both of these protections and others providing none.

Many scholars strongly endorse the adoption of audit privilege laws, stressing the need for protection against the risks of disclosure, including potential criminal or state civil liability as well as bad publicity and exposure to citizen suits (Kesan 2000; Murray 1999; Geltman \& Mathews 1997;

\footnotetext{
${ }^{11}$ For example, when encouraging facilities to review their prior regulatory reports and self-disclose any errors or emissions, US EPA has warned that facilities that fail to do so "will be targeted for potential enforcement inspections," which "could result in an enforcement action." (US EPA's "Show Cause Letter Regarding EPCRA Section 312 Sector Agreement" and "Asphalt letter”, both obtained via a Freedom of Information Act Request )
} 
Goldsmith \& King 1997; Grayson \& Landgraf 1997; Hunt \& Wilkins 1992). Such enthusiasm for audit privilege is typically based on the argument that companies will not self-disclose violations without strict protection for their audit materials. For example, Hunt \& Wilkins (1992:366) note: "Unless current law and existing policies are modified to broaden confidentiality privileges, ... powerful disincentives to self-examination will remain.”

Immunity provides a different way of protecting voluntary disclosers, preserving state regulators' access to all relevant information about a violation, but preventing them from prosecuting a company for voluntarily disclosed violations. In many ways, state immunity statutes simply mimic the protection that most federal voluntary programs already provide. However, this protection can be important because facilities often face overlapping state and federal regulatory obligations, and without immunity, information disclosed under a federal voluntary program could later be used against them by state regulators.

A large survey of manufacturing facilities in the US conducted in 1998 found that nearly a third of these facilities that were not conducting internal audits attributed this to a concern that a regulatory agency might attempt to obtain an audit report and use this information for enforcement actions (Morandi 1998). A majority of such facilities located in states without immunity or privilege laws claimed they would begin conducting internal audits if their state passed such laws (Morandi 1998). These theoretical arguments and claims by company representatives have been subjected to little empirical evaluation. We remedy this by examining the extent to which state-level statutory audit privilege encourages organizations to self-report compliance infractions.

\subsection{COMMUNITY PRESSURE}

Institutional pressures from community groups, such as local citizens and environmental groups, represent another important element of an organization's legal environment. Several studies have found that company decisions to adopt environmental management practices are influenced by 
the desire to improve or maintain relations with their communities. The desire to improve community relations has influenced firms to adopt environmental plans (Henriques \& Sadorsky 1996), pollution prevention activities and environmental management systems (Florida \& Davison 2001), community advisory panels (Lynn, Busenberg, Cohen, \& Chess 2000), and the ISO 14001 Environmental Management System Standard (Raines 2002). Local community and activist group demands, backed by the threat of adverse publicity, citizen suits, or reports to local government regulators, can also encourage facilities to improve their environmental performance, creating a kind of "social license” with which firms must comply in addition to their legal and regulatory obligations (Thornton, Kagan, \& Gunningham 2003). This body of research suggests that community pressure induces companies to go above and beyond what the law requires to maintain their community ties. Because self-reporting violations can be viewed as another manifestation of exhibiting responsible corporate citizenship, we predict that organizations that face more community pressure are more likely to self-report regulatory compliance violations.

\subsection{ORGANIZATIONAL CHARACTERISTICS}

Organizations do not respond uniformly to pressures in their legal environment. Neoinstitutional studies have shown that the normative pressures to comply with regulatory requirements are stronger on firms that are more prominent or visible within their legal environment, either because of their size or because of their ties to the public (Edelman 1990). High profile firms are more sensitive to their legal environment for several reasons. Firms with high public visibility "receive more attention from regulators, the media, and the public, and they are therefore held to higher standards of institutional compliance than smaller organizations” (Ingram \& Simons 1995:1468). This extra attention makes them more vulnerable to normative pressures (Goodstein 1994; Ingram \& Simons 1995) because these firms must "maintain their social legitimacy" 
(Goodstein 1994:376) and preserve their reputation (May 2004). ${ }^{12}$ Greater public scrutiny may also make it more difficult for such firms to hide violations or atone for them if discovered (Scott \& Meyer 1983). Finally, these firms are more likely to have a "culture of formal rules" and "rational legal authority” (Edelman 1990:1415), with many already subject to strict reporting obligations; thus, they may be more likely to have in place a "reporting culture" that would facilitate environmental self-regulation. Consequently, we hypothesize that organizations with greater public visibility will be more likely to self-disclose regulatory violations.

\section{METHODS}

\subsection{SAMPLE}

Our sampling approach attempts to surmount a major limitation of much self-regulation empirical research. Because the homogeneity of interests among similar firms fosters the bonds that facilitate effective self-monitoring (Rees 1994), many empirical studies of self-regulation have focused on a single industry or, in some cases, a handful of firms (e.g., Rees 1994, King \& Lenox 2000, Gunningham, Kagan \& Thornton 2003, Rivera \& de Leon 2004, Welch, Mazur \& Bretschneider 2000). Our sample spans a wide variety of industries, which should produce more generalizable insights about the dynamics of industry self-regulation. In addition, our approach enables us to examine whether the determinants and effects of self-policing differ across industries.

Our sampling frame includes manufacturing and other facilities engaged in pollutionintensive industries with 10 or more employees that manufacture, process, or use significant amounts of toxic chemicals (typically above 10,000 pounds) ${ }^{13}$ that are subject to both the US Resource

\footnotetext{
${ }^{12}$ In addition, there are fixed costs associated with becoming familiar with regulatory requirements. Therefore, larger firms and firms with multiple facilities within a common regulatory regime can leverage economies of scale in compliance-oriented tasks. For example, once a firm develops an audit protocol to ensure compliance, this protocol can often be leveraged across many of its facilities with only minor revisions.

${ }^{13}$ Specifically, our sampling frame includes facilities that are required to submit data to the US EPA's Toxic Release Inventory (TRI) program. The TRI program applies to facilities engaged in manufacturing as well as those in the following industries: most metal and coal mining, most electrical utilities, hazardous waste treatment and disposal facilities, chemical wholesalers, petroleum terminals and bulk stations, solvent recovery service providers, and all federal facilities (US EPA 2002a).
} 
Conservation and Recovery Act (RCRA) and the US Clean Air Act (CAA). ${ }^{14}$ Facilities are subject to

RCRA regulations if they generate, manage, store, or treat hazardous waste, and are subject to CAA provisions if they emit air pollutants beyond regulatory thresholds. We focus on these federal regulations because they are arguably the most broadly applicable to our sample of facilities.

\subsection{MEASURES}

We measured voluntary disclosure as a dummy variable, coded 1 for a facility in a year when it disclosed a compliance violation in conjunction with the US EPA Audit Policy. We constructed the most comprehensive dataset possible of Audit Policy self-disclosures by drawing on data from three sources: the US EPA Integrated Compliance Information System (ICIS) database, the (hardcopy) US EPA Audit Policy Docket, and lists of facilities that disclosed under the Audit Policy in response to the Compliance Incentive Programs, discussed below. ${ }^{15}$ We present total number of facilities self-disclosing violations to the Audit Policy for each year of our sample in Table A-1 in the Appendix.

We measure the specific deterrence effect of inspections and inspector-discovered violations (Cohen 2000) using data from US EPA's Resource Conservation and Recovery Act Information (RCRAInfo) database and Aerometric Information Retrieval System/AIRS Facility Subsystem (AIRS/AFS) database. ${ }^{16}$ We measure whether a facility had an enforcement action based on data obtained from US EPA's ICIS database. In our empirical models for the selection analysis, we lagged each of these variables one year.

\footnotetext{
${ }^{14}$ In any particular year, an operating facility may release pollutants below TRI reporting thresholds and not be subjected to any inspections. In such years, we recoded missing values from these facilities to zero if we had evidence the facility was active both prior to and subsequent to that "quiet” year. In making this determination, we considered any of the following activity: (a) submitted any data to the TRI program; (b) had an inspection or violation recorded in the US EPA's Resource Conservation and Recovery Act Information (RCRAInfo) database or Aerometric Information Retrieval System/AIRS Facility Subsystem (AIRS/AFS) database; or (c) had an enforcement action or voluntary disclosure recorded in the US EPA Integrated Compliance Information System (ICIS) database.

${ }^{15}$ Discussions with US EPA revealed that both the ICIS database and the Docket were incomplete, which led us to create our dataset based these sources as well as participant lists for Compliance Incentive Programs.

${ }^{16}$ To reduce the potential influence of outliers, for each of the variable we recoded values above the $99^{\text {th }}$ percentile to the $99^{\text {th }}$ percentile value.
} 
We considered two types of general deterrence. First, we considered the facilities and sectors that were targeted by US EPA Compliance Incentive Programs that encouraged them to review their compliance status and consider self-disclosing violations via the Audit Policy. US EPA typically announces Compliance Incentive Programs via its Enforcement Alert newsletter, the Federal Register, and its website. Facilities may also learn about these programs through trade associations. We gathered data about Compliance Incentive Programs via a Freedom of Information Act Request of the US EPA. ${ }^{17}$ The second form of general deterrence we considered are US EPA National Priority Sectors. US EPA announces its two-year priorities in Memoranda of Agreement, which we obtained from the agency's website. ${ }^{18}$ Because US EPA typically announces its National Priorities the year before they take effect, we considered facilities to be targeted by National Priorities for three years: the announcement year and the two years they were in effect. Because some National Priorities are implemented through Compliance Incentive Programs, we created three dummy variables to reduce multicollinearity: (1) National Priority Sector and Compliance Incentive Program Target; (2) National Priority Sector only; and (3) Compliance Incentive Program Target only.

We created two dummy variables to indicate whether a facility was located in a state that provided audit privilege and/or immunity in a given year. ${ }^{19}$ We constructed these variables using data from Morandi (1998), US EPA's Audit Policy website, and a private web service run by the

\footnotetext{
${ }^{17}$ Compliance Incentive Programs that affected our sample include the National Iron \& Steel Mini-mills Program, National Industrial Organic Chemicals Program, National Nitrate Compounds Program, Region 1 Chemical Industry Program, and Region 5 Iron \& Steel Mini-mill Program. US EPA Region 1 includes Connecticut, Maine, Massachusetts, New Hampshire, Rhode Island, and Vermont, and Region 5 includes Illinois, Indiana, Michigan, Minnesota, Ohio, and Wisconsin.

${ }^{18}$ National Priority sectors in our sample include chemical preparation (1998-9), coal-fired power plants (1996-9), industrial organic chemicals (1996-9), iron and basic steel products (1996-9), metal electroplating and coating (2000-3), mining (1996-7), petroleum refining (1996-2003), plastic materials and synthetics (1996-7), primary nonferrous metals (1996-9), printers (1996-7), and pulp mills (1996-9).

http://www.epa.gov/compliance/data/planning/shortterm.html (last updated March 17, 2005)

${ }^{19}$ As described earlier, state audit privilege laws prevent state regulatory agencies and private parties from obtaining any documents produced in connection with an internal environmental audit or using them in court against a voluntary discloser. States immunity statutes prevent self-reporters from being prosecuted for violations they voluntarily report.
} 
Auditing Roundtable. ${ }^{20}$ We resolved any inconsistencies by referring to the actual statutory language in LEXIS-NEXIS state statutory databases. Our coding of this variable is presented in Table A-2 in the Appendix.

While others have used qualitative methods to assess the impact of actual community pressure on facilities’ environmental behavior (e.g., Gunningham, Thornton \& Kagan 2005), we believe companies may self-disclose violations based not only on the actual threats they face from their community, but on the community's potential to organize and pose such threats. As such, we conceptualize community pressure as a function of its potential ability to detect violations and exert political influence. Firms in more densely populated areas are likely to be subjected to greater pressure to strictly comply with environmental laws (Kagan et al. 2004) because there is a greater chance that a community member might observe evidence of compliance infractions such as spills into surface waters or releases of black smoke. ${ }^{21}$ Population density was calculated as the average number of residents per square mile in the facility’s Census Tract based on the US Census Bureau's 2000 Decennial Census. To reduce the influence of outliers, we recoded values outside the $1^{\text {st }}$ and $99^{\text {th }}$ percentiles to these limits, and take the log of the trimmed values. We capture a community's potential to apply political pressure by considering income and voter turnout. Communities with higher household income are expected to be more connected to politicians, and thus represent a greater threat to facilities. We calculated log household income within each facility's Census Tract using data from the 2000 Decennial Census. We employ voter turnout as a proxy for a community’s level of political awareness and participation (Hamilton 1993; 1999). We measured voter turnout as the proportion of residents aged 18 and over in the facility's county who voted for a Presidential

\footnotetext{
${ }^{20}$ The EPA’s Audit Policy website is http://www.epa.gov/region5/orc/audits/audit apil.htm (last updated April 6, 2004). Auditing Roundable data is available from http://www.auditing-roundtable.org

${ }^{21}$ Densely populated areas also contain numerous business and employment options, which suggests that citizens and local officials will tend to be less beholden to a corporate polluter than those in smaller locales where a single industrial employer may be a critical source of jobs.
} 
candidate in the 2000 general election. ${ }^{22}$ County population data were obtained from the 2000 Decennial Census, and voting data were obtained from Lublin \& Voss (2001) for all states except Alaska.

We measure a facility’s public visibility using three organizational characteristics: facility revenues, firm-wide revenues, and whether the facility is a member of a publicly-owned company (Edelman 1990). We obtained data on revenues and ownership status from Dun \& Bradstreet for all self-disclosers and a random sample of non-disclosers in the same industries. ${ }^{23}$ To leverage the data for our full sample, we also estimated facility size as the nationwide average revenues per establishment within each 4-digit SIC Code using data from the 1997 Economic Census, the latest year available.

To control for potential unobserved differences between industries, we create dummy variables for each 2-digit SIC Code to reflect the facility’s industry. We created dummies for the ten EPA Regions to control for differences in their inspection coverage and enforcement strategies (US GAO 2000). ${ }^{24}$ Because the prevailing ideology of US Circuit Courts has been shown to influence company decisions (Guthrie and Roth 1999), we control for the possibility that the composition of the federal judiciary might affect the self-reporting decisions of companies. Judges' political ideology has been shown to affect their decision-making on a wide range of issues including environmental issues (Malmsheimer \& Floyd 2004, Revesz 2001). We use the political party of the president who appointed the judges as a proxy for the judges’ own political ideology (Humphries \& Songer 1999; Tate \& Handberg 1991; Spence \& Murray 1999; Schultz \& Petterson 1992), calculating the proportion of all Court of Appeals judges who served during 1990-1994 (the last year

\footnotetext{
${ }^{22}$ To reduce the potential influence of outliers, we recoded values above the $99^{\text {th }}$ percentile to the $99^{\text {th }}$ percentile value. The county is the smallest geographic unit for which we could locate voting data across the United States.

${ }^{23}$ Funding constraints prevented us from obtaining data on revenues and ownership status for all facilities in the sample.

${ }^{24}$ A recent report by the US General Accounting Office noted substantial variation across EPA Regions in terms of inspection coverage, enforcement staff, the number and type of enforcement actions taken, and criteria used to determine penalty assessments, and the size of penalties assessed (US GAO 2000).
}

Comment: Page: 18
LATER:
brand prominence: We measure brand
prominence as a dummy variable coded 1
for facilities that are affiliated with any of
Business Week's “Top 100 Brands” lists
during 2001-2004 (Business Week 2001;
2002; 2003; 2004). We identified all
corporate affiliates of these brands using
the Directory of Corporate Affiliations
database via Lexis-Nexis.
Business Week (2001) “The 101 Top
Brands,” 6 Aug., p. 60.
Business Week (2002) “The 100 Top
Brands,” 5 Aug., p. 95.
Business Week (2003) “The 100 Top
Brands,” 5Aug., p. 72.
Business Week (2004) “The 100 Top
Brands” 2 Aug., p. 64.
Corporate affiliate of a top 100 bre ... [1]

Brands” 2 Aug., p. 64

Corporate affiliate of a top $100 \mathrm{~b}$ 
for which data are available) that were nominated by a Democratic President, using data from Zuk, Barrow \& Gryski (1996). We use the average proportion appointed by Democrat Presidents for each Circuit over 1990-1994 as our measure of Federal Circuit Court ideology. ${ }^{25}$ Table A-3 in the Appendix presents our coding of this variable.

Descriptive statistics and correlations of all variables are provided in Tables 1 and 2.

\section{EMPIRICAL MODEL AND RESULTS}

To identify which factors influence facilities to self-disclose violations, we model selfdisclosure as a dichotomous decision made by each facility in each year. We employ a pooled probit model with dummies to control for differences between industries (2-digit SIC Code), years, and EPA Regions. Because we could obtain revenues and ownership data for only on a small subset of our sample, we employ two alternative specifications. Model 1 excludes those variables to avail a much larger sample size; Model 2 includes them. ${ }^{26}$

Table 3 presents the probit results of the participation analysis, with robust standard errors clustered by facility. With few exceptions, which we describe below, the statistical significance of determinants was robust to these different specifications. To interpret the magnitude of effects, we calculate the marginal effects based on an infinitesimal change of continuous variables, a unit change in count variables, or a discrete change in dummy variables (Columns $1 \mathrm{~b}$ and $2 \mathrm{~b}$ ). To evaluate these marginal effects in the context of the model estimations, we divide these marginal effects by the probability of disclosure evaluated at mean of all variables, and present these results in Columns 1c

\footnotetext{
${ }^{25}$ While we could have used just the most recent value pertaining to each Circuit Court (1994), we felt that using the average of the prior 5 years (1990-1994) better reflects the overall impression of the court and reduces the influence of any aberrations that may occur in any single year.

${ }^{26}$ We looked for evidence of misspecification using the "link test" in Stata. After the initial fit of a model, the predicted value and its square are generated. The original dependent variable is then regressed on these two variables. In both models, the predicted value was statistically significant, while the prediction squared was not significant, indicating the models are not misspecified. The predicted value (y_hat) was highly significant at $\mathrm{p}<0.000$ in both Models, and the squared predicted value (y_hat_squared) was not significant at $\mathrm{p}=0.76$ in Model 1 and $\mathrm{p}=0.56$ in Model 2.
} 
and 2c. This provides marginal effects as a percent increase or decrease in the probability of disclosure compared to the probability predicted from all variable means.

The statistically significant positive coefficients on inspections and enforcement actions support our hypothesis that specific deterrence measures encourage self-disclosure. The results of Models 1 and 2, respectively, suggest that an additional RCRA inspection increases the probability of selfdisclosure the next year by $16 \%$ to $35 \%(\mathrm{p}<0.01),{ }^{27}$ and that an additional CAA inspection increases this probability by $8 \%$ to $14 \%(\mathrm{p}<0.05)$. Being subject to at least one enforcement action-a much rarer event-had a much greater influence on disclosure, as our results suggest that this doubles (Model 2) or triples (Model 1) the likelihood of self-disclosing the next year $(\mathrm{p}<0.05)$ compared to the probability evaluated at the means of all variables. We found no evidence that the number of RCRA or CAA violations had any influence on the decision to self-disclose a violation the subsequent year (controlling for inspections). ${ }^{28}$

As for general deterrence mechanisms, facilities targeted by a US EPA Compliance Incentive Program were significantly more likely to self-disclose violations. A facility targeted by both a Compliance Incentive Program and a National Priority Sector was 3 to 4 times more likely to selfdisclose a violation that year than the average facility targeted by neither program. A facility targeted by just a Compliance Incentive Program (and not a National Priority Sector) was 14 to 20 times more likely to self-disclose a violation that year. However, we found no evidence that a facility targeted only as a National Priority Sector—and not simultaneously targeted by a Compliance Incentive Program — was any more likely to self-disclose than facilities that were not targeted by either program.

\footnotetext{
${ }^{27}$ The marginal effects, evaluated at the mean value of all variables, of an additional RCRA inspection range from 0.0006 (Model 1) to 0.0053 (Model 2). The probability of disclosure evaluated at the mean value of all variables is 0.0039 in Model 1 and 0.0150 in Model 2. Thus our results indicate that an additional RCRA inspection increases the probability of disclosure in the subsequent year by $16 \%(0.0006 \div 0.0039$, for Model 1$)$ to $35 \%(0.0053 \div$ 0.0150, for Model 2).

${ }^{28}$ In addition, the coefficients on the two violations variables are not jointly significantly different from zero at conventional levels, nor is their sum.
} 
While the coefficients on the statutory immunity and audit privilege variables are positive, as predicted, they are not statistically significant in either model. ${ }^{29}$ Because our statutory variables were measured at the state-level, we re-ran our models clustering the standard errors by state. In Model 1, the statutory immunity coefficient is statistically significant $(\mathrm{p}=0.03)$ and its magnitude suggests that a facility located in a state that offers statutory immunity that year is $20 \%$ more likely to self-disclose a violation compared to the probability based on all variables at their means. The coefficient on statutory audit privilege in Model 1 remained insignificant regardless of our clustering technique. In Model 2, neither the individual coefficients on immunity or audit privilege nor their sum is significant at conventional levels, regardless of whether standard errors were clustered by facility or state. Overall, we find some evidence that disclosure is more likely when statutory immunity is provided, but no evidence that statutory audit privilege has any influence.

We found support for our hypothesis that more prominent facilities were more likely to selfdisclose violations, as the facility- and firm-level revenue variables were consistently positive and statistically significant. ${ }^{30}$ To interpret the magnitude of the effects, we rely on Model 2, which uses actual measures of facility and firm-wide revenues (as opposed to the facility-level proxy used in Model 1). A one log-unit increase from the means of either log facility revenues or log firm-wide revenues is associated with a $14 \%$ increase in the likelihood of self-disclosing compared to the probability evaluated at the mean of all variables. Contrary to our expectations, we found no evidence that facilities owned by publicly held firms were more likely to self-report than privately held companies. We also found no evidence that any of our three measures of community pressure

\footnotetext{
${ }^{29}$ While the coefficient on each of these variables was not significant at conventional levels, their sum was moderately significant $(\mathrm{p}=0.07)$ in Model 1 . This provides some evidence that statutory protection encourages disclosure, though in this specification we cannot discern which protection is more important

${ }^{30}$ Because we measured facility size in Model 1 at the 4-digit SIC Code level (facility sub-industry revenues), we reran our models clustering standard errors by 4-digit SIC Codes. The statistical significance of this coefficient was unchanged.
} 
(population density, average per capita income, and voter turnout) had any affect on facilities' decision to self-disclose violations. ${ }^{31}$

\section{DISCUSSION, CONCLUSION AND FUTURE RESEARCH}

\subsection{DISCUSSION}

Our findings suggest that even as voluntary industry self-regulation programs proliferate, government still has an important role to play. We have shown that violators are more likely to selfreport when they are subject to regulatory pressure, including being inspected, punished and targeted by focused compliance initiatives. In fact, self-reporting is not deterred even by ostensibly hostile relations with regulators. Firms that recently experienced enforcement actions, which involve significant legal costs and often result in penalties and injunctive relief, are much more likely to selfdisclose than those with fewer compliance problems. In addition, we find little evidence that statelevel legal protections that seek to incentivize self-reporting by tying local regulators' hands encourage firms to self-report. Together, these findings support a regulatory policy that recognizes the ongoing importance of state regulation and regulators to the success of public-private regulatory partnerships. Contrary to what many have suggested, we find no support for the argument that the state should continue to withdraw from the regulatory arena, leaving firms to police themselves without supervision.

Our finding that more inspections encourage self-disclosure complements related research showing that more frequent inspections improve compliance (Magat \& Viscusi 1990; Laplante \& Rilstone 1996, Gunningham, Thornton \& Kagan 2005; Gray \& Shadbegian 2005; Kuperan \& Sutinen 1998; Winter \& May 2001; Braithwaite \& Makkai 1991). ${ }^{32}$ Building on this prior work, our results suggest that such coercive, deterrent regulatory techniques may continue to be necessary even in a

\footnotetext{
${ }^{31}$ The coefficients on these three variables are not jointly significantly different from zero at conventional levels, nor is their sum. Because these variables were measured at the Census Tract and County levels, we re-ran our models clustering standard errors by Census Tracts. The coefficients continued to be individually and jointly insignificant, as did their sum.

${ }^{32}$ For example, Magat \& Viscusi (1990) found that pulp and paper plants in the United States halved their noncompliance rates in the quarter following an inspection.
} 
more cooperative regulatory environment. Because regulators consider a facility’s “motivation” and “willingness to comply” when prioritizing their enforcement activities (US EPA 1992), facilities that have faced more inspections recently may be particularly keen to convey a "pro-compliance” image to convince regulators of their motivation and willingness to comply. One way facilities may attempt to do this is by self-disclosing their violations and agreeing to bolster their internal audit processes. Given these results, it remains clear that the Audit Policy supplements, but cannot replace, regulatory inspections. What the US EPA noted in 1990 apparently still holds in the era of voluntary selfpolicing: "Inspections remain the backbone of agency compliance monitoring programs....Even with widespread requirements for self-monitoring, inspections play a major role in assuring quality and lending credibility to self-monitoring programs” (Wasserman 1990).

Our general deterrence results similarly suggest the ongoing importance of regulatory oversight to the success of self-policing. Self-reporting was more likely among facilities targeted by US EPA Compliance Incentive Programs, which are often announced directly to target firms through letters or trade associations and typically offer technical compliance assistance along with the incentives of the Audit Policy. On the other hand, we find no evidence that facilities targeted by industry-wide US EPA National Priorities were any more likely to voluntarily self-disclose violations than those in other industries. A number of factors may explain this apparent disparity. For example, facilities in National Priority sectors might not be aware that they are a target, since they are not notified via letters from US EPA or trade associations, as typically occurs with Compliance Incentive Programs. Even if they are aware that they are within a National Priority sector, such facilities may believe that scrutiny of a broadly defined industry does not significantly increase the chances of having their violations detected, whereas Compliance Incentive Programs often target fewer than 100 facilities--and in some cases as few as 20. In any event, our results suggest an interesting convergence of compliance/deterrence strategies that has yet to be developed in the literature: general deterrence is more effective the more targeted or "specific" it is. 
Contrary to prior research that showed that more inspector-discovered violations led facilities to improve their compliance (Gray \& Scholz 1993; Helland 1998), we find no evidence that violation frequency increases the likelihood of self-disclosures. The mere presence of inspectors at a facility, or the threat of their arrival through targeted compliance initiatives, apparently encourages selfreporting regardless of what they find once they get there. This discrepancy may result from differences between compliance and self-policing behavior: firms previously cited by inspectors for violations only stand to gain from cleaning up their act and complying with regulations; however, it is less clear whether disclosing additional violations to regulators will engender goodwill.

While we found some evidence (Model 1, but not Model 2) that facilities are more likely to self-disclose violations if their state provides statutory immunity, facilities shielded by state-level statutory audit privilege were no more likely to self-report violations. While our results cannot conclusively explain the different impact of these two statutory protections, audit privilege laws may fail to encourage self-reporting because firms have a variety of incentives to conduct internal compliance audits apart from self-policing. If this is correct, audit privilege shields will not affect the likelihood of self-policing and self-reporting, but will only provide cover for corporate wrongdoing after the fact. Our finding on audit privilege confirms the results of a 1998 survey, which found that facilities self-disclosed violations and conducted internal audits at the same rate regardless of whether they were protected by statutory audit privilege protection (Morandi 1998). Taken together, these results demand a thoughtful re-examination of the many economic and policy arguments in support of secrecy for audit materials and broader protections for corporate polluters.

US EPA and environmental groups have long resisted the enactment of audit privilege laws on the grounds that they deprive the public of access to information that is crucial to health and safety and make discovery of and prosecution for unreported violations much more difficult (Bedford 1996, Woodall 1997). As the US EPA said in announcing the Audit Policy, "privilege, by definition, invites secrecy, instead of the openness needed to build public trust in industry's ability to self- 
police” (US EPA 1995:66710). Access to internal facility data is especially important in a regulatory system that has come increasingly to rely on information disclosure as its own instrument of compliance. Rechtshaffen (2004), for instance, discusses the success that US EPA has had in improving Clean Water Act compliance by publicly disclosing information about facility performance. We find that restricting access to such information through an evidentiary privilege deprives regulators and the public of a potentially valuable compliance tool without providing any countervailing benefit in the form of increased self-reporting. Our findings provide better support for immunity protection, which unequivocally encourages self-reporting and does so while preserving public access to important health and safety information.

Contrary to several existing studies and to our own expectations, our study yielded little evidence that potential community pressure influenced company decisions to participate in selfpolicing activities. Our "non-result" may be due to the inadequacy of our measures or to more complex relationships than those we modeled. For example, the influence of well-organized communities may work through regulators, with communities applying pressure on regulatory enforcement agencies, who respond by increasing inspection frequency and the likelihood of pursuing enforcement actions against facilities. Our model cannot distinguish the impact of such community pressure from the regulatory pressure it produces. Selection bias may also mute the impact of our community pressure variables if companies choose where to locate their facilities based (at least in part) on expectations about their ability to meet community demands. Finally, selfpolicing may exhibit a different dynamic than compliance in this arena as well. Firms under pressure from their communities might be conflicted about whether self-disclosing will enhance or detract from their legitimacy and corporate citizenship reputation, depending on whether citizen stakeholders view the disclosure as an act of honesty and goodwill, or as mere confirmation that violations are in fact occurring. It is possible that our non-result represents the two sides of the disclosure coin effectively canceling out one another. 
We found that more prominent facilities-whether measured by more employees or revenues - are more likely to self-disclose violations. This may result because larger organizations have a greater need to preserve their reputation (May 2004)—especially since compliance reputation may spillover between facilities of the same firm and because they believe their heightened public scrutiny reduces their ability to hide their violations (Scott \& Meyer 1983). ${ }^{33}$ Together, these considerations may provide a compelling motivation for larger facilities to self-disclose. More generally, our finding is consistent with other empirical studies that have found that larger organizations are more likely to acquiesce to institutional pressures (e.g., Goodstein 1994; Ingram and Simons 1995).

\subsection{FUTURE RESEARCH}

Our results suggest several avenues of future research. More empirical research is needed to better understand the influence of communities on companies' self-regulation behavior. Future research would benefit by leveraging qualitative research that describes how communities influence facilities’ environmental behavior (e.g., Gunningham, Thornton \& Kagan 2005) to develop largescale quantitative measures of actual community pressure to improve upon our measures of potential community pressure. Future research evaluating the influence of community pressures on companies' behavior should also examine the extent to which companies select facility sites based on their expectations about community pressures and their ability to meet community demands. A better understanding of this process could effectively address the endogeneity concerns we raised in discussing our results.

While we have identified a number of factors that influence self-reporting, there are undoubtedly more explanations for this complex behavior. Future research might attend to other factors such as the composition of Boards of Directors or the prior employment of key managers. It

\footnotetext{
${ }^{33}$ Teasing these factors apart represents an opportunity for future research.
} 
would also be useful to learn whether institutionalized compliance mechanisms like Environmental Management Systems encourage self-reporting. Such research could compare and contrast the dynamics between self-reporting and compliance.

Finally, future evaluations of self-policing should focus on outcomes. For example, to what extent does self-policing actually elicit regulatory goodwill? Researchers could answer this question by examining whether self-disclosing leads to fewer inspections, more flexible enforcement, lower penalties, and faster permitting. Beyond benefits to the regulated community, researchers should also examine whether self-policing improves public welfare. For example, researchers could examine to the conditions under which self-policing actually improves regulatory compliance and furthers the ultimate objectives of these regulations. In the environmental context, for example, we would urge researchers to examine the conditions under which self-policing reduces the risk of harm to public health and the environment.

\subsection{CONCLUSIONS}

Self-regulation and self-policing have been touted as a new paradigm of regulation that trades outmoded “command-and-control” strategies for industry-directed, market-based solutions. While it is hard to deny that there are benefits to fostering more cooperative relationships between the regulators and the regulated, our research counsels caution in the face of arguments that coercive regulatory strategies are ineffective or obsolete and that government should cede to corporations the unfettered authority to regulate themselves. Offered the option of self-policing under the Audit Policy, companies were apparently willing to come clean only under the threat that they might be caught instead. Even as corporations are given an expanding role in their own governance, our study shows that the success of "voluntary" self-policing depends on the continued involvement of regulators with coercive powers. 


\section{REFERENCES}

Anderson, Eric E. \& Wayne K.Talley (1995) "The oil spill size of tanker and barge accidents: Determinants and policy implications,” 71 Land Economics 216-228.

Aoki, Kazumasu \& John W. Coiffi (2000). "Poles apart: Industrial waste management regulation and enforcement in the United States and Japan," in Robert A. Kagan \& Lee Axelrod, eds., Regulatory Encounters. Berkeley, CA: University of California Press.

Ayres, Ian, and John Braithwaite (1992) Responsive Regulation: Transcending the Deregulation Debate. New York: Oxford University Press.

Bardach, Eugene, and Robert A. Kagan (1982) Going by the Book: The Problem of Regulatory Unreasonableness. Philadelphia: Temple University Press.

Bedford, Christopher. (1996). Dirty Secrets: The Corporations' Campaign for an Environmental Audit Privilege. Takoma Park, MD: Environmental Action Foundation. http://www.mapcruzin.com/scruztri/docs/r2.htm

Braithwaite, J., \& T. Makkai (1991) “Testing an Expected Utility Model of Corporate Deterrence,” 25 Law \& Society Review 7-40.

Cohen, Mark A. (1987) "Optimal Enforcement Strategy to Prevent Oil Spills: An Application of Principal-Agent Model with Moral Hazard,” 30 Journal of Law and Economics 23-51.

Cohen, Mark A. (2000) "Empirical Research on the Deterrence Effect of Environmental Monitoring and Enforcement,” 30 Environmental Law Reporter 10245-10252.

Cox, James. (2004) "The Case Against a Judicially Created, Common-Law Self-Audit or Self-Evaluation Privilege Applicable to Environmental Cases," 51 Fordham Environmental Law Journal 1-30.

Delmas, Magali \& Michael W. Toffel (2005) "Institutional Pressure and Environmental Management," University of California Center for Responsible Business Working Paper, Berkeley, CA.

DiMaggio, Paul J. \& Walter W. Powell (1991) "Introduction,” in Walter W. Powell \& Paul J. DiMaggio, eds., The New Institutionalism in Organizational Analysis. Chicago: University of Chicago Press.

Dimento, Joseph F. (1989) "Can Social Science Explain Organizational Noncompliance with Environmental Law? 45(1) Journal of Social Issues 109-132.

Dobbin, Frank, \& John R. Sutton (1998) "The Strength of a Weak State: The Rights Revolution and the Rise of the Human Resources Management Divisions," 104 American Journal of Sociology 441476.

Duggin, Sarah Helene (2003) "Internal Corporate Investigations: Legal Ethics, Professionalism and the Employee Interview,” 2003 Columbia Business Law Review: 859-964.

Edelman, Lauren B. (1990) "Legal Environments and Organizational Governance: The Expansion of Due Process in the Workplace," 95 American Journal of Sociology 1401-1440.

Edelman, Lauren B. (1992) "Legal Ambiguity and Symbolic Structures: Organizational Mediation of Civil Rights Law,” 97 American Journal of Sociology 1531-1576.

Edelman, Lauren B. \& Mark C. Suchman. (1997) “The Legal Environments of Organizations,” 23 Annual Review of Sociology 479-515.

Edelman, Lauren B., Christopher Uggen, \& Howard S. Erlanger (1999) "The Endogeneity of Legal Regulation: Grievance Procedures as Rational Myth," 105(2) American Journal of Sociology 40654. 
Eden, Sally (1996) Environmental Issues and Business: Implications of a Changing Agenda. Chichester, England: John Wiley \& Sons.

Epple, Dennis, \& Michael Visscher (1984) “Environmental Pollution: Modeling Occurrence, Detection and Deterrence,” 27 Journal of Law and Economics 29-60.

Federal Register (1995) "Incentives for Self-Policing: Discovery, Disclosure, and Prevention of Violations,” 60 Federal Register 66706-66712.

Federal Register (1999) "Evaluation of 'Incentives for Self-Policing: Discovery, Disclosure, and Prevention of Violations’ Policy Statement, Proposed Revisions for Public Comment,” 64 Federal Register 26745-26756.

Fleder, John R. (1999) “A Voluntary Disclosure Program for FDA - The Time Has Come,” 54 Food and Drug Law Journal 389-399.

Florida, R., \& D. Davison (2001) "Gaining from green management: Environmental management systems inside and outside the factory,” 43(3) California Management Review 64-84.

Friedman, Lawrence (1975) The Legal System: A Social Science Perspective. New York: Russell Sage Foundation.

Geltman, Elizabeth Glass, \& Carey Ann Mathews (1997) "Environmental Law and Business in the 21st Century: Environmental Democracy,” 22 Iowa Journal of Corporate Law 395-410.

Gibbs, Jack (1986) “Deterrence Theory and Research,”in G. Melton, ed., The Law as a Behavioral Instrument. Lincoln, Nebraska: University of Nebraska Press.

Goldsmith, Michael, \& Chad W. King (1997) "Policing Corporate crime: The Dilemma of Internal Compliance Programs,” 50 Vanderbilt Law Review 1-47.

Goodstein, Jerry D. (1994) "Institutional Pressures and Strategic Responsiveness: Employer Involvement in Work-Family Issues,” 37(2) Academy of Management Journal 350-382.

Gray, Wayne, \& Mary E. Deily (1996) "Compliance and Enforcement: Air Pollution Regulation in the US Steel Industry,” 31 Journal of Environmental Economics and Management 96-111.

Gray, Wayne, \& John T. Scholz (1991) “Analyzing the Equity and Efficiency of OSHA Enforcement,” 13 Law \& Policy 185-214.

Gray, Wayne B \& John T. Scholz (1993) "Does Regulatory Enforcement Work? A Panel Analysis of OSHA Enforcement,” 27 Law \& Society Review 177-213.

Gray, Wayne, \& Ronald Shadbegian (2005) "When and Why Do Plants Comply? Paper mills in the 1980s,” 27(2) Law \& Policy 238-261.

Grayson, E. Lynn, \& Christina M. Landgraf (1997) "EPA’s Audit Policy and State Audit Privilege Laws: Moving Beyond Command and Control?” 27 Environmental Law Reporter 10243.

Gunningham, Neil (1995) "Environment, Self-regulation, and the Chemical Industry: Assessing Responsible Care," 17(1) Law \& Policy 57-108.

Gunningham, Neil, \& Peter Grabosky (1998) Smart Regulation: Designing Environmental Policy. Oxford: Clarendon Press.

Gunningham, Neil, Robert A. Kagan, \& Dorothy Thornton (2003) Shades of Green: Regulation, Business, Enforcement. Palo Alto: Stanford University Press.

Gunningham, Neil, Dorothy Thornton, \& Robert A. Kagan (2004) "Motivating Management: Corporate Compliance in Environmental Protection," in JSP/Center for the Study of Law and Society Faculty Working Papers. Berkeley, CA. 
Gunningham, Neil, Dorothy Thornton, \& Robert A. Kagan (2005) "Motivating Management: Corporate Compliance in Environmental Protection,” 27(2) Law \& Policy 289-316.

Guthrie, Doug, \& Louise Marie Roth (1999) “The State, Courts, and Maternity Policies in U.S. Organizations: Specifying Institutional Mechanisms,” 64 American Sociological Review 41-63.

Hamilton, James T. (1993) "Politics and Social Costs: Estimating the Impact of Collective Action on Hazardous Waste Facilities,” 24(1) RAND Journal of Economics 101-125.

Hamilton, James T. (1999) "Exercising Property Rights to Pollute: Do Cancer Risks and Politics Affect Plant Emission Reductions?” 18(2) Journal of Risk and Uncertainty 105-124.

Harrington, Winston (1988) “Enforcement Leverage when Penalties are Restricted,” 37 Journal of Public Economics 29-53

Heckman, J. J., H. Ichimura, \& P. Todd (1997) "Matching as an Econometric Evaluation Estimator: Evidence from Evaluating a Job Training Programme,” 64(4) The Review of Economic Studies 605-654.

Heckman, J. J., H. Ichimura, \& P. Todd (1998) "Matching as an Econometric Evaluation Estimator," 65(2) The Review of Economic Studies 261-294.

Helland, Eric (1998) "The Enforcement of Pollution Control Laws: Inspections, Violations, and SelfReporting,” 80(1) The Review of Economics and Statistics 141-153.

Henriques, Irene, \& Perry Sadorsky, (1996) “The Determinants of an Environmentally Responsive Firm: An Empirical Approach,” 30(3) Journal of Environmental Economics and Management 381-395.

Humphries, Martha A., \& Donald R. Songer (1999) "Law and Politics in Judicial Oversight of Federal Administrative Agencies,” 61(1) Journal of Politics 207-220.

Hunt, Terrell E., \& Timothy A. Wilkins (1992) “Environmental Audits and Enforcement Policy,” 16 The Harvard Environmental Law Review 365-427.

Ingram, Paul, \& Tal Simons (1995) "Institutional and Resource Dependence Determinants of Responsiveness to Work-Family Issues,” 38(5) Academy of Management Journal 1466-1482.

Innes, Robert (2001) "Violator Avoidance Activities and Self-Reporting in Optimal Law Enforcement," 17 Journal of Law, Economics \& Organizations 239-256.

Kagan, Robert. A., Neil Gunningham, \& Dorothy Thornton (2003) “Explaining Corporate Environmental Performance: How Does Regulation Matter?” 37(1) Law \& Society Review 51-90.

Kagan, Robert A., \& John T. Scholz (1984) "The Criminology of the Corporation and Regulatory Enforcement Styles,” in K. Hawkins \& J.M. Thomas, eds., Enforcing Regulation. Boston: Kluwer Academic Pub.

Kaplow, Louis, \& Steven Shavell (1994) “Optimal Law Enforcement with Self-Reporting of Behavior,” 102 Journal of Political Economy 583-606.

Kesan, Jay P. (2000) "Innovations in Environmental Policy: Encouraging Firms to Police Themselves: Strategic Prescriptions to Promote Corporate Self-Auditing,” University of Illinois Law Review 155-184.

Khanna, Madhu, \& Lisa Damon (1999) "EPA's Voluntary 33/50 Program: Impact on Toxic Releases and Economic Performance of Firms,” 37 Journal of Environmental Economics and Management 125.

King, Andrew A., \& Michael J. Lenox (2000) "Industry Self-Regulation Without Sanctions: The Chemical Industry's Responsible Care Program,” 43 Academy of Management Journal 698-716. 
Kuperan, K., \& Jon G. Sutinen (1998) "Blue Water Crime: Deterrence, Legitimacy, and Compliance in Fisheries,” 32 Law \& Society Review 309-330.

Laplante, Benoît, \& Paul Rilstone (1996) "Environmental Inspections and Emissions of the Pulp and Paper Industry in Quebec,” 31(1) Journal of Environmental Economics and Management 19-36

Lenox, Michael J., \& Jennifer Nash (2003) "Industry Self-Regulation and Adverse Selection: A Comparison Across Four Trade Association Programs,” 12 Business Strategy and the Environment 343-356.

Lublin, David, \& D. Stephen Voss (2001) “Federal Elections Project”. American University, Washington, DC and the University of Kentucky. http://www.american.edu/academic.depts/spa/ccps/fepindex.html

Lynn, Frances M., George Busenberg, Nevin Cohen, \& Caron Chess (2000) “Chemical Industry's Community Advisory Panels: What Has Been Their Impact?” 34(10) Environmental Science and Technology 1881-1886.

Klein, Jill, \& Hiraj Dawar (2004) “Corporate Social Responsibility and Consumers' Attributions and Brand Evaluations in a Product-Harm Crisis,” 21 International Journal of Research in Marketing 203-217.

Magat, Wesley A., \& W. Kip Viscusi (1990) "Effectiveness of the EPA's Regulatory Enforcement: The Case of Industrial Effluent Standards,” 33 Journal of Law and Economics 331-360.

Malmsheimer, Robert W., \& Donald W. Floyd (2004) "US Courts of Appeals judges' review of Federal Natural Resource Agencies' Decisions,”17(6) Society and Natural Resources 533-546.

May, Peter J. (2004) “Compliance Motivations: Affirmative and Negative Bases,” 38 Law \& Society Review 41-68.

Medinger, Jason D. (2003) “Antitrust Leniency Programs: A Call for Increased Harmonization as Proliferating Programs Undermine Deterrence,”52 Emory Law Journal 1439-1481.

Mendelhoff, John, \& Wayne Gray (2005) “Inside OSHA’s Black Box: What is the Link between Inspections, Citations, and Reductions in Different Injury Type?” 27(2) Law \& Policy 219-237.

Meyer, John W., \& Brian Rowan (1977) “Institutionalized Organizations: Formal Structure as Myth and Ceremony,” 83 American Journal of Sociology 340-363.

Morandi, Larry (1998) State Environmental Audit Laws and Policies: An Evaluation. Denver: National Conference of State Legislatures.

Murray, Paula C. (1999) “Inching Toward Environmental Regulatory Reform -- ISO 14000: Much Ado About Nothing or a Reinvention Tool?” 37 American Business Law Journal 35-71.

Orts, Eric W. (1995) “Reflexive Environmental Law,” 89 Northwestern University Law Review 12271340.

Paternoster, Raymond, and Sally Simpson (1996) "Sanction Threats and Appeals to Morality: Testing a Rational Choice Model or Corporate Crime," 30(3) Law \& Society Review 549-584.

Peloza, John (2005), “Corporate Social Responsibility as Reputation Insurance,” Paper presented at the $2^{\text {nd }}$ Annual Corporate Social Performance Conference, Haas School of Business, University of California, Berkeley, April.

Peterson, Melody, \& Christopher Drew (2003) "The Slaughterhouse Gamble: The Risk of Self-Policing; New Safety Rules Fail to Stop Tainted Meat,” New York Times, 10 Oct., sec. A, p. 1. 
Pfaff, Alexander S.P., \& Chris W. Sanchirico (2000) "Environmental Self-Auditing: Setting the Proper Incentives for Discovery and Correction of Environmental Harm,” 16 Journal of Law, Economics \& Organizations 189-208.

Pfaff, Alexander S.P., \& Chris W. Sanchirico (2004) "Big Field, Small Potatoes: An Empirical Assessment of EPA's Self-Audit Policy,” 23(3) Journal of Policy Analysis and Management 415432.

Raines, S. S. (2002) “Implementing ISO 14001--An international survey assessing the benefits of certification, 9(4) Corporate Environmental Strategy 418-426.

Rechtschaffen, C. (2004). "Enforcing the Clean Water Act in the Twenty-First Century: Harnessing the Power of the Public Spotlight,” 55 Alabama Law Review 775-814.

Rees, Joseph V. (1994) Hostages of Each Other: The Transformation of Nuclear Safety Since Three Mile Island. Chicago: University of Chicago Press.

Revesz, R.L. (2001) “Federalism and Environmental Regulation: A Public Choice Analysis,” 115(2) Harvard Law Review 553-641.

Rivera, Jorge, \& Peter de Leon (2004) "Is Greener Whiter? The Sustainable Slopes Program and the Voluntary Environmental Performance of Western Ski Areas,” 32(3) Policy Studies Journal 417437.

Rosenbaum, Paul R., \& Donald B. Rubin (1983) "The Central Role of the Propensity Score in Observational Studies for Causal Effects,” 70(1) Biometrika 41-55.

Ross, H. Laurence (1982) “Interrupted Time Series Studies of Deterrence of Drinking and Driving,” in J. Hagan, ed., Deterrence Reconsidered: Methodological Innovations. Beverly Hills: Sage Publications.

Scholz, John T. (1984) “Cooperation, Deterrence, and the Ecology of Regulatory Enforcement,” 18(2) Law \& Society Review 179-224.

Schultz, Vicki, \& Stephen Petterson (1992) "Race, Gender, Work and Choice: An Empirical Study of the Lack of Interest Defense in Title VII Cases Challenging Job Segregation,” 59 University of Chicago Law Review 1073-1181.

Scott, W. Richard, \& John W. Meyer (1983) “The Organization of Societal Sectors,” in J.W. Meyer \& W.R. Scott, eds., Organizational Environments: Ritual and Rationality. Beverly Hills, CA: Sage.

Spence, David B., \& Paula Murray (1999) “The Law, Economics, and Politics of Federal Preemption Jurisprudence: A Quantitative Analysis” 87 California Law Review 1125-1206

Tate, C. Neal \& Roger Handberg (1991) "Time Binding and Theory Building in Personal Attribute Models of Supreme Court Voting Behavior, 1916-88,” 35(2) American Journal of Political Science 460-480.

Thornton, Dorothy, Robert A. Kagan, \& Neil Gunningham (2003) "Sources of Corporate Environmental Performance,” 46(1) California Management Review 127-141.

Thornton, Dorothy, Neil Gunningham, \& Robert A. Kagan (2005) “General Deterrence and Corporate Environmental Behavior,” 27(2) Law \& Policy 262-288.

Toffel, Michael W. (2005) "Resolving Information Asymmetries in Markets: The Role of Certified Voluntary Management Programs," Unpublished manuscript, Haas School of Business, University of California at Berkeley.

Tyler, Tom (1990) Why People Obey the Law. New Haven: Yale University Press. 
US EPA (1990) Environmental Enforcement: A Citizen's Guide. Washington DC: United States Environmental Protection Agency, Office Of Enforcement (March), http://www.epa.gov/region4/air/enforce/citizenf.htm

US EPA (1992) "Identifying the Regulated Community and Establishing Program Priorities, Chapter 4 in Principles of Enforcement. Washington DC: US Environmental Protection Agency. EPA Number 300F93001, www.inece.org/enforcementprinciples.html

US EPA. (1995) “Incentives for Self-Policing: Disclosure, Correction, and Prevention of Violations,” 60 Fed. Reg. 66706.

US EPA (2002a) The Toxics Release Inventory (TRI) and Factors to Consider When Using TRI Data. Washington DC: United States Environmental Protection Agency, http://www.epa.gov/tri/2002_tri_brochure.pdf

US EPA (2002b) User's Manual for RSEI Version 2.1 [1988-2000 TRI Data]. Washington, DC: US Environmental Protection Agency.

US GAO (2000) Environmental Protection: More Consistency Needed Among EPA Regions In Approach To Enforcement. Washington DC: United States General Accounting Office (Report GAO/RCED-00-108).

Vandenbergh, Michael (2003) "Beyond Elegance: A Testable Typology of Social Norms in Corporate Environmental Compliance,” 22 Stanford Environmental Law Journal 55-144.

Wasserman, Cheryl E. (Acting Director, Office of Enforcement Policy, Office of Enforcement, U.S. Environmental Protection Agency) (1990) "An Overview of Compliance and Enforcement in the United States: Philosophy, Strategies, and Management Tools,” First International Enforcement Workshop Proceedings, International Network for Environmental Compliance and Enforcement, Utrecht, The Netherlands (May), http://www.inece.org/1stvol1/1stTOC.htm

Welch, Eric W., Allan Mazur, \& Stuart Bretschneider (2000) "Voluntary Behavior by Electric Utilities: Levels of Adoption and Contribution of the Climate Challenge Program to the Reduction of Carbon Dioxide," 19 Journal of Policy Analysis and Management 407-425.

Winter, Soeren C., \& Peter J. May (2001) "Motivation for Compliance with Environmental Regulations,” 20 Journal of Policy Analysis \& Management 675-698.

Woodall, Mark (Sierra Club Audit Privilege Task Force) (1997) “Secrecy Bills Derailed in States,” The Planet 4(1). www.sierraclub.org/planet/199701/states.asp

Zuk, Gary, Deborah J. Barrow, \& Gerard S. Gryski (1996) “A Multi-User Database On The Attributes Of U.S. Appeals Court Judges, 1801-1994 [Computer file]. 1st ICPSR version.” Gary Zuk, Deborah J. Barrow, \& Gerard S. Gryski, Auburn University [producers], 1996. Ann Arbor, MI: Interuniversity Consortium for Political and Social Research [distributor], 1997. 
TABLE 1

VARIABLE DEFINITIONS AND SUMMARY STATISTICS

\begin{tabular}{|c|c|c|c|c|c|}
\hline Variable & Definition & $\begin{array}{l}\text { Facility- } \\
\text { year } \\
\text { obs. }\end{array}$ & Mean & SD & $\begin{array}{c}\text { Min Max } \\
\text { (For dummies, } \\
\text { number coded 1) }\end{array}$ \\
\hline $\begin{array}{l}\text { Self-disclosure via the } \\
\text { Audit Policy (this year) }\end{array}$ & $\begin{array}{l}\text { Dummy coded } 1 \text { in a year when a facility } \\
\text { discloses a violation under the US EPA Audit } \\
\text { Policy }\end{array}$ & 88094 & 0.01 & 0.09 & 650 \\
\hline RCRA inspections & $\begin{array}{l}\text { Number of inspections per year pertaining to the } \\
\text { US Resource Conservation and Recovery Act }\end{array}$ & 77353 & 0.43 & 0.84 & 4 \\
\hline CAA inspections & $\begin{array}{l}\text { Number of inspections per year pertaining to the } \\
\text { US Clean Air Act }\end{array}$ & 87306 & 1.08 & 1.57 & 0 \\
\hline RCRA violations & $\begin{array}{l}\text { Number of violations per year pertaining to the } \\
\text { US Resource Conservation and Recovery Act }\end{array}$ & 77353 & 0.40 & 1.31 & 0 \\
\hline CAA violations & $\begin{array}{l}\text { Number of violations per year pertaining to the } \\
\text { US Clean Air Act }\end{array}$ & 87306 & 0.05 & 0.21 & 0 \\
\hline Any enforcement actions & $\begin{array}{l}\text { Dummy coded } 1 \text { in a year when the US EPA } \\
\text { brought an enforcement action against a facility }\end{array}$ & 88094 & 0.02 & 0.16 & 2196 \\
\hline $\begin{array}{l}\text { CIP target and National } \\
\text { Priority sector }\end{array}$ & $\begin{array}{l}\text { Dummy coded } 1 \text { in a year when the facility was } \\
\text { among those targeted by a US EPA Compliance } \\
\text { Incentive Program (CIP) and was a US EPA } \\
\text { National Priority sector }\end{array}$ & 88094 & 0.01 & 0.08 & 556 \\
\hline $\begin{array}{l}\text { CIP target but not } \\
\text { National Priority sector }\end{array}$ & $\begin{array}{l}\text { Dummy coded } 1 \text { in a year when the facility was } \\
\text { among those targeted by a US EPA CIP but was } \\
\text { not a US EPA National Priority sector }\end{array}$ & 88094 & 0.01 & 0.07 & 444 \\
\hline $\begin{array}{l}\text { National Priority sector } \\
\text { but not CIP target }\end{array}$ & $\begin{array}{l}\text { Dummy coded } 1 \text { in a year when the facility’s } \\
\text { industry was named as US EPA National } \\
\text { Priority sector but was not targeted by a CIP }\end{array}$ & 88094 & 0.15 & 0.36 & 13045 \\
\hline State audit privilege & $\begin{array}{l}\text { Dummy coded } 1 \text { in years when a facility's state } \\
\text { provides statutory audit privilege }\end{array}$ & 88094 & 0.45 & 0.50 & 39402 \\
\hline State immunity & $\begin{array}{l}\text { Dummy coded } 1 \text { in years when a facility's state } \\
\text { provides statutory immunity }\end{array}$ & 88094 & 0.34 & 0.48 & 30296 \\
\hline $\begin{array}{l}\text { Log population density in } \\
2000\end{array}$ & $\begin{array}{l}\text { Population density during } 2000 \text { of the facility’s } \\
2000 \text { Census Tract }\end{array}$ & 88094 & 2.36 & 0.08 & 2.74 \\
\hline $\begin{array}{l}\text { Log per capita income in } \\
1999\end{array}$ & $\begin{array}{l}\text { Per capita income in } 1999 \text { of the facility’s } 2000 \\
\text { Census Tract }\end{array}$ & 88094 & 9.73 & 0.85 & $0.00 \quad 12.05$ \\
\hline $\begin{array}{l}\text { Voter turnout in } 2000 \\
\text { (county) }\end{array}$ & $\begin{array}{l}\text { Percent of population who voted for US } \\
\text { President in the } 2000 \text { elections in the facility's } \\
\text { county }\end{array}$ & 88094 & 0.52 & 0.08 & 0.79 \\
\hline $\begin{array}{l}\text { Log facility sub-industry } \\
\text { revenues in } 1997 \text { (SIC4) }\end{array}$ & $\begin{array}{l}\text { Average revenues per facility in } 1997 \text { in the } \\
\text { facility’s 4-digit SIC Code }\end{array}$ & 87242 & 9.65 & 1.24 & 6.8314 .63 \\
\hline $\begin{array}{l}\text { Log facility revenues in } \\
2004\end{array}$ & Facility revenues in 2004 & 10978 & 17.37 & 2.02 & $\begin{array}{ll}10.37 & 24.35\end{array}$ \\
\hline $\begin{array}{l}\text { Log firm-wide revenues } \\
\text { in } 2004\end{array}$ & Facility’s firm-wide revenues in 2004 & 14407 & 20.53 & 2.72 & $11.70 \quad 26.42$ \\
\hline Publicly owned in 2004 & $\begin{array}{l}\text { Dummy coded } 1 \text { if the facility was owned by a } \\
\text { publicly-traded company in } 2004\end{array}$ & 15138 & 0.54 & 0.50 & 8180 \\
\hline $\begin{array}{l}\text { Federal Circuit Court } \\
\text { ideology (US Circuit) }\end{array}$ & $\begin{array}{l}\text { Percent of US Circuit Court's judges in 1990-94 } \\
\text { appointed by Democratic presidents in the } \\
\text { facility's US Circuit }\end{array}$ & 88094 & 0.32 & 0.10 & 0.47 \\
\hline
\end{tabular}


TABLE 2

\section{CORRELATIONS}

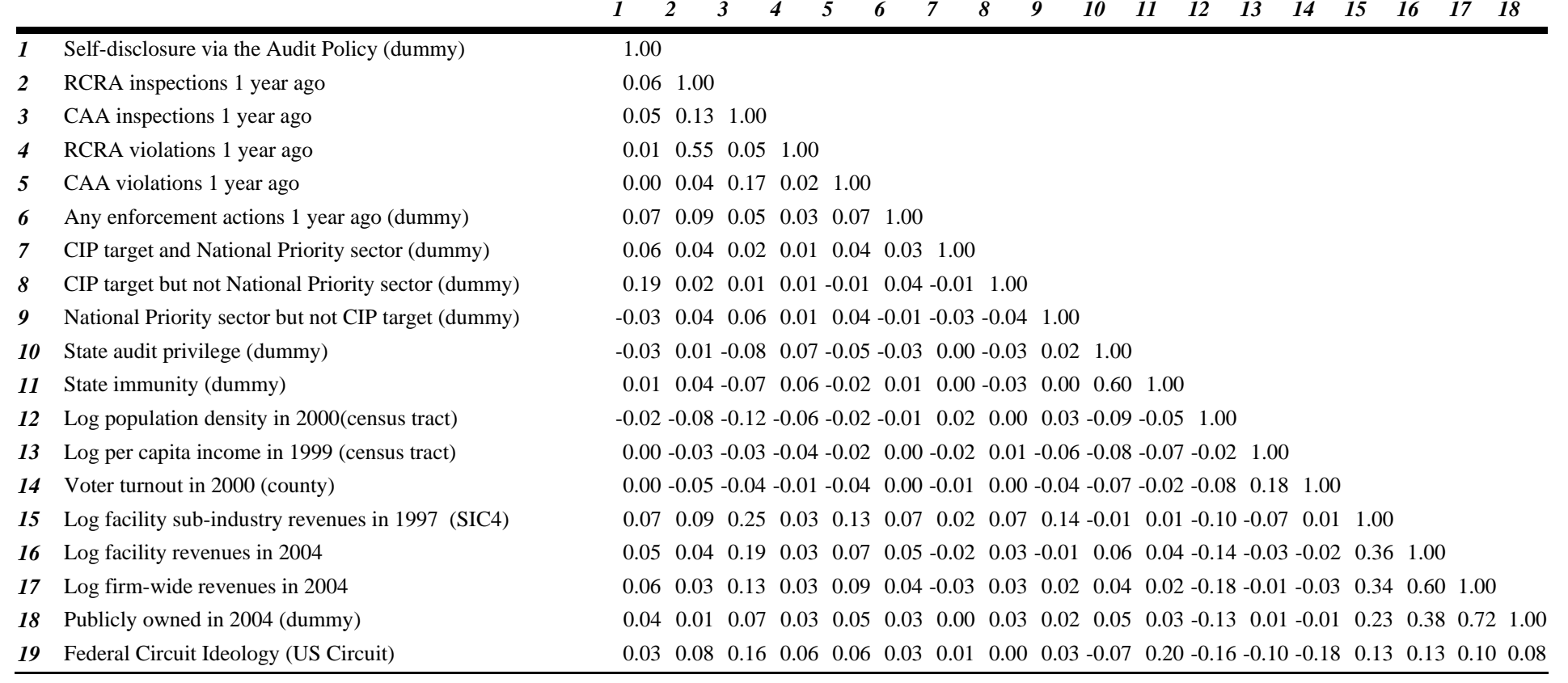

Notes: 5981 facility-year observations. RCRA = Resource Conservation and Recovery Act; CAA = Clean Air Act; CIP = Compliance Incentive Program 
TABLE 3: WHO PARTICIPATES IN THE AUDIT POLICY?

Dependent variable: Probability of self-disclosure

\begin{tabular}{|c|c|c|c|c|c|c|c|}
\hline & \multirow{2}{*}{\multicolumn{3}{|c|}{ Model 1}} & \multirow{2}{*}{\multicolumn{3}{|c|}{ Model 2}} \\
\hline & & & & & & & \\
\hline & & & (1b) & (1c) & $(2 a)$ & (2b) & $(2 \mathrm{c})$ \\
\hline & & $\begin{array}{c}\text { Probit } \\
\text { coefficient }\end{array}$ & $\begin{array}{c}\text { Marginal } \\
\text { effect }\end{array}$ & $\begin{array}{c}\text { Marginal } \\
\text { effect to } \\
\text { baseline } \\
\text { probability }\end{array}$ & $\begin{array}{c}\text { Probit } \\
\text { coefficient }\end{array}$ & $\begin{array}{c}\text { Marginal } \\
\text { effect }\end{array}$ & $\begin{array}{l}\text { Marginal } \\
\text { effect to } \\
\text { baseline } \\
\text { probability }\end{array}$ \\
\hline \multirow[t]{5}{*}{$\begin{array}{l}\text { Specific } \\
\text { deterrence }\end{array}$} & RCRA evaluations 1 year ago & $\begin{array}{l}0.05 \\
{[0.02]^{* *}}\end{array}$ & $0.0006 \leftrightarrow$ & $16 \%$ & $\begin{array}{l}0.14 \\
{[0.04]^{* *}}\end{array}$ & $0.0053 *$ & $35 \%$ \\
\hline & CAA inspections 1 year ago & $\begin{array}{l}0.03 \\
{[0.01]^{*}}\end{array}$ & $0.0003 *$ & $8 \%$ & $\begin{array}{l}0.06 \\
{[0.02]^{*}}\end{array}$ & $0.0021 \leftrightarrow$ & $14 \%$ \\
\hline & RCRA violations 1 year ago & $\begin{array}{l}-0.01 \\
{[0.01]}\end{array}$ & $-0.0001 *$ & $-2 \%$ & $\begin{array}{l}-0.03 \\
{[0.03]}\end{array}$ & -0.0012 & $-8 \%$ \\
\hline & CAA violations 1 year ago & $\begin{array}{c}0.01 \\
{[0.07]}\end{array}$ & $0.0001 *$ & $3 \%$ & $\begin{array}{l}-0.09 \\
{[0.15]}\end{array}$ & $-0.0033 \leftrightarrow$ & $-22 \%$ \\
\hline & Any enforcement actions 1 year ago & $\begin{array}{c}0.39 \\
{[0.06]^{* *}}\end{array}$ & 0.0074 & $190 \%$ & $\begin{array}{c}0.28 \\
{[0.13] *}\end{array}$ & 0.0138 & $92 \%$ \\
\hline \multirow[t]{3}{*}{$\begin{array}{l}\text { General } \\
\text { deterrence }\end{array}$} & CIP target \& National Priority sector & $\begin{array}{l}0.58 \\
{[0.12]^{* *}}\end{array}$ & 0.0146 & $374 \%$ & $\begin{array}{c}0.52 \\
{[0.24]^{*}}\end{array}$ & 0.0341 & $227 \%$ \\
\hline & CIP target but not National Priority sector & $\begin{array}{l}1.29 \\
{[0.08]^{* *}}\end{array}$ & $0.0803 \bullet$ & $2059 \%$ & $\begin{array}{l}1.41 \\
{[0.22]^{* *}}\end{array}$ & $0.2052 \bullet$ & $1368 \%$ \\
\hline & National Priority sector but not CIP target & $\begin{array}{l}-0.07 \\
{[0.06]}\end{array}$ & -0.0007 & $-18 \%$ & $\begin{array}{l}-0.23 \\
{[0.14]}\end{array}$ & -0.0075 & $-50 \%$ \\
\hline \multirow[t]{2}{*}{$\begin{array}{l}\text { Statutory } \\
\text { provisions }\end{array}$} & State audit privilege & $\begin{array}{c}0.02 \\
{[0.06]}\end{array}$ & 0.0002 & $5 \%$ & $\begin{array}{l}0.03 \\
{[0.13]}\end{array}$ & 0.0011 & $7 \%$ \\
\hline & State immunity & $\begin{array}{c}0.07 \\
{[0.06]}\end{array}$ & 0.0008 & $21 \%$ & $\begin{array}{c}0.05 \\
{[0.12]}\end{array}$ & $0.0019 \bullet$ & $13 \%$ \\
\hline \multirow[t]{3}{*}{$\begin{array}{l}\text { Community } \\
\text { pressure }\end{array}$} & Log population density in 2000 (census tract) & $\begin{array}{l}-0.08 \\
{[0.26]}\end{array}$ & -0.0009 & $-23 \%$ & $\begin{array}{l}-0.75 \\
{[0.56]}\end{array}$ & -0.0285 & $-190 \%$ \\
\hline & Log per capita income in 1999 (census tract) & $\begin{array}{l}-0.01 \\
{[0.02]}\end{array}$ & -0.0001 & $-3 \%$ & $\begin{array}{c}0.01 \\
{[0.05]}\end{array}$ & 0.0005 & $3 \%$ \\
\hline & Voter turnout in 2000 (county) & $\begin{array}{c}0.33 \\
{[0.28]}\end{array}$ & 0.0038 & $97 \%$ & $\begin{array}{c}0.57 \\
{[0.66]}\end{array}$ & 0.0215 & $143 \%$ \\
\hline \multirow[t]{4}{*}{ Prominence } & $\begin{array}{l}\text { Log facility sub-industry revenues in } 1997 \\
\text { (SIC4) }\end{array}$ & $\begin{array}{l}0.11 \\
{[0.02]^{* *}}\end{array}$ & 0.0013 & $33 \%$ & & & \\
\hline & Log facility revenues in 2004 & & & & $\begin{array}{c}0.05 \\
{[0.03]+}\end{array}$ & 0.0021 & $14 \%$ \\
\hline & Log firm-wide revenues in 2004 & & & & $\begin{array}{c}0.06 \\
{[0.03]^{*}}\end{array}$ & 0.0021 & $14 \%$ \\
\hline & Publicly owned in 2004 & & & & $\begin{array}{l}-0.16 \\
{[0.11]}\end{array}$ & -0.0058 & $-39 \%$ \\
\hline Controls & $\begin{array}{l}\text { Federal Circuit Court ideology } \\
\text { Industry fixed-effects } \\
\text { Year fixed-effects } \\
\text { EPA Region fixed-effects }\end{array}$ & $\begin{array}{l}\mathrm{Y} \\
\mathrm{Y} \\
\mathrm{Y} \\
\mathrm{Y}\end{array}$ & & & $\begin{array}{l}\mathrm{Y} \\
\mathrm{Y} \\
\mathrm{Y} \\
\mathrm{Y}\end{array}$ & & \\
\hline \multicolumn{2}{|c|}{$\begin{array}{l}\text { Observations (facility-years) } \\
\text { Facilities } \\
\text { Log likelihood intercept only } \\
\text { Log likelihood full model } \\
\text { Likelihood ratio } \\
\text { Pseudo R-squared } \\
\text { Probability of disclosure evaluated at mean of all variables }\end{array}$} & $\begin{array}{c}87242 \\
13591 \\
-3679.82 \\
-3224.05 \\
911.53^{* *} \\
0.12 \\
0.0039\end{array}$ & & & $\begin{array}{c}6751 \\
1006 \\
-819.17 \\
-696.54 \\
245.26^{* *} \\
0.15 \\
0.0150\end{array}$ & & \\
\hline \multicolumn{8}{|c|}{$\begin{array}{l}\text { "Marginal effect" is the change in the probability of adoption, evaluated at the mean all variables, based on an infinitesimal } \\
\text { change in each continuous independent variable, a unit change in each count variable (denoted *), or a discrete change in each } \\
\text { dummy variable (denoted } \bullet \text { ). "Marginal effect to baseline probability" is the marginal effect as a proportion of the probability of } \\
\text { disclosure evaluated at mean of all variables. Brackets contain robust standard errors clustered by facility. ** } p<0.01 \text {; * p }<0.05 \text {; + } \\
\text { p }<0.10 \text {. All specifications include dummy variables to control for industry (2-digit SIC Codes), EPA Region, and Year, and the } \\
\text { proportion of US Circuit Court judges appointed by a Democratic President. RCRA = Resource Conservation and Recovery Act; } \\
\text { CAA = Clean Air Act; CIP = Compliance Incentive Program }\end{array}$} \\
\hline
\end{tabular}




\section{APPENDIX \\ TABLE A-1 \\ FACILITIES DISCLOSING VIOLATIONS TO THE AUDIT POLICY}

(1)

All facilities
(2)

All facilities TRI Reporters ${ }^{\text {a }}$ Entire sample ${ }^{b}$

\begin{tabular}{lcccc}
\hline 1997 & 457 & 153 & 62 & 43 \\
1998 & 950 & 251 & 103 & 61 \\
1999 & 990 & 412 & 222 & 100 \\
2000 & & 773 & 412 & 200 \\
2001 & 1754 & 603 & 296 & 161 \\
2002 & & 777 & 187 & 104 \\
2003 & 614 & 520 & 171 & 79 \\
Total during 1997-2003 & & & & $\mathbf{7 4 8}$ \\
Source: & & $\mathbf{3 4 8 9}$ & $\mathbf{1 4 5 3}$ & O48 \\
\hline
\end{tabular}

Data in column 1 were obtained from various US EPA reports and newsletters that provided updates on participation in the Audit Policy. The other columns reflect facility-level data we obtained from three sources via Freedom of Information Act requests: the US EPA Integrated Compliance Information System (ICIS) database, the (hardcopy) US EPA Audit Policy Docket, and lists of facilities that disclosed under the Audit Policy in response to the Compliance Incentive Programs. According to discussions with US EPA, the disparities between the database we constructed from US EPA databases and documents and US EPA's own aggregate figures are likely due to several factors, including: (1) their reports typically refer to fiscal years rather than calendar years; (2) US EPA does not necessarily enter facility-level data into their databases when a corporation simultaneously discloses tens or hundreds of violations across multiple facilities; and (3) data coding errors or omissions.

${ }^{a}$ This column refers to facilities that report data to the US EPA Toxic Release Inventory (TRI) program.

b This column refers to facilities that report data to the US EPA Toxic Release Inventory (TRI) program and are subject to hazardous waste regulations pursuant to the Resource Conservation and Recovery Act (RCRA) and air regulations pursuant to the Clean Air Act (CAA). We use this sample in our analysis. 
TABLE A-2

INTERNAL AUDIT STATUTORY PROTECTIONS: PRIVILEGE AND IMMUNITY

\begin{tabular}{|c|c|c|c|c|c|c|c|c|c|c|c|c|c|c|c|c|c|c|c|}
\hline & 1995 & 1996 & 1997 & 1998 & 1999 & 2000 & 2001 & 2002 & 2003 & & 1995 & 1996 & 1997 & 1998 & 1999 & 2000 & 2001 & 2002 & 2003 \\
\hline AK & $\sim$ & $\sim$ & $\mathrm{I} \& \mathrm{P}$ & I\&P & $\mathrm{I} \& \mathrm{P}$ & $I \& P$ & I\&P & I\&P & I\&P & MT & $\sim$ & $\sim$ & I & I & I & I & I & $\sim$ & $\sim$ \\
\hline $\mathrm{AL}$ & $\sim$ & $\sim$ & $\sim$ & $\sim$ & $\sim$ & $\sim$ & $\sim$ & $\sim$ & $\sim$ & $\mathrm{NC}$ & $\sim$ & $\sim$ & $\sim$ & $\sim$ & $\sim$ & $\sim$ & $\sim$ & $\sim$ & $\sim$ \\
\hline $\mathrm{AR}$ & $\mathrm{P}$ & $\mathrm{P}$ & $\mathrm{P}$ & $\mathrm{P}$ & $\mathrm{P}$ & $\mathrm{P}$ & $\mathrm{P}$ & $\mathrm{P}$ & $\mathrm{P}$ & ND & $\sim$ & $\sim$ & $\sim$ & $\sim$ & $\sim$ & $\sim$ & $\sim$ & $\sim$ & $\sim$ \\
\hline $\mathrm{AZ}$ & $\sim$ & $\sim$ & $\sim$ & $\sim$ & $\sim$ & $\sim$ & $\sim$ & $\sim$ & $\sim$ & $\mathrm{NE}$ & $\sim$ & $\sim$ & $\sim$ & $\mathrm{I} \& \mathrm{P}$ & $\mathrm{I} \& \mathrm{P}$ & $\mathrm{I} \& \mathrm{P}$ & $\mathrm{I} \& \mathrm{P}$ & $\mathrm{I} \& \mathrm{P}$ & $\mathrm{I} \& \mathrm{P}$ \\
\hline $\mathrm{CA}$ & $\sim$ & $\sim$ & $\sim$ & $\sim$ & $\sim$ & $\sim$ & $\sim$ & $\sim$ & $\sim$ & $\mathrm{NH}$ & $\sim$ & $\mathrm{I} \& \mathrm{P}$ & $\mathrm{I} \& \mathrm{P}$ & I\&P & $\mathrm{I} \& \mathrm{P}$ & $\mathrm{I} \& \mathrm{P}$ & I\&P & I\&P & $\sim$ \\
\hline $\mathrm{CO}$ & $\mathrm{I} \& \mathrm{P}$ & $\mathrm{I} \& \mathrm{P}$ & $\mathrm{I} \& \mathrm{P}$ & $\mathrm{I} \& \mathrm{P}$ & $\mathrm{I} \& \mathrm{P}$ & $\mathrm{I} \& \mathrm{P}$ & $\mathrm{I} \& \mathrm{P}$ & $\mathrm{I} \& \mathrm{P}$ & $\mathrm{I} \& \mathrm{P}$ & $\mathrm{NJ}$ & $\mathrm{I}$ & $\mathrm{I}$ & I & I & I & I & I & $\mathrm{I}$ & $\mathrm{I}$ \\
\hline CT & $\sim$ & $\sim$ & $\sim$ & $\sim$ & $\sim$ & $\sim$ & $\sim$ & $\sim$ & $\sim$ & NM & $\sim$ & $\sim$ & $\sim$ & $\sim$ & $\sim$ & $\sim$ & $\sim$ & $\sim$ & $\sim$ \\
\hline DC & $\sim$ & $\sim$ & $\sim$ & $\sim$ & $\sim$ & $\sim$ & $\sim$ & $\sim$ & $\sim$ & NV & $\sim$ & $\sim$ & I\&P & $I \& P$ & I\&P & I\&P & I\&P & I\&P & $\mathrm{I} \& \mathrm{P}$ \\
\hline$\overline{\mathrm{DE}}$ & $\sim$ & $\sim$ & $\sim$ & $\sim$ & $\sim$ & $\sim$ & $\sim$ & $\sim$ & $\sim$ & $\mathrm{NY}$ & $\sim$ & $\sim$ & $\sim$ & $\sim$ & $\sim$ & $\sim$ & $\sim$ & $\sim$ & $\sim$ \\
\hline FL & $\sim$ & $\sim$ & $\sim$ & $\sim$ & $\sim$ & $\sim$ & $\sim$ & $\sim$ & $\sim$ & $\mathrm{OH}$ & $\sim$ & $\sim$ & $\mathrm{I} \& \mathrm{P}$ & I\&P & $\mathrm{I} \& \mathrm{P}$ & $\mathrm{I} \& \mathrm{P}$ & I\&P & I\&P & $\mathrm{I} \& \mathrm{P}$ \\
\hline GA & $\sim$ & $\sim$ & $\sim$ & $\sim$ & $\sim$ & $\sim$ & $\sim$ & $\sim$ & $\sim$ & OK & $\sim$ & $\sim$ & $\sim$ & $\sim$ & $\sim$ & $\sim$ & $\sim$ & $\sim$ & $\sim$ \\
\hline $\mathrm{HI}$ & $\sim$ & $\sim$ & $\sim$ & $\sim$ & $\sim$ & $\sim$ & $\sim$ & $\sim$ & $\sim$ & OR & $\mathrm{P}$ & $\mathrm{P}$ & $\mathrm{P}$ & $\mathrm{P}$ & $\mathrm{P}$ & $\mathrm{P}$ & $\mathrm{P}$ & $\mathrm{P}$ & $\mathrm{P}$ \\
\hline IA & $\sim$ & $\sim$ & $\sim$ & $\mathrm{I} \& \mathrm{P}$ & $\mathrm{I} \& \mathrm{P}$ & $\mathrm{I} \& \mathrm{P}$ & I\&P & I\&P & $\mathrm{I} \& \mathrm{P}$ & PA & $\sim$ & $\sim$ & $\sim$ & $\sim$ & $\sim$ & $\sim$ & $\sim$ & $\sim$ & $\sim$ \\
\hline ID & $\mathrm{I} \& \mathrm{P}$ & $\mathrm{I} \& \mathrm{P}$ & I\&P & $\sim$ & $\sim$ & $\sim$ & $\sim$ & $\sim$ & $\sim$ & RI & $\sim$ & $\sim$ & $\mathrm{I}$ & $\mathrm{I}$ & $\mathrm{I}$ & $\mathrm{I}$ & $\mathrm{I}$ & $\mathrm{I}$ & $\mathrm{I}$ \\
\hline IL & $\mathrm{P}$ & $\mathrm{P}$ & $\mathrm{P}$ & $\mathrm{P}$ & $\mathrm{P}$ & $\mathrm{P}$ & $\mathrm{P}$ & $\mathrm{P}$ & $\mathrm{P}$ & SC & $\sim$ & $\mathrm{I} \& \mathrm{P}$ & $\mathrm{I} \& \mathrm{P}$ & $\mathrm{I} \& \mathrm{P}$ & $\mathrm{I} \& \mathrm{P}$ & $\mathrm{I} \& \mathrm{P}$ & I\&P & $\mathrm{I} \& \mathrm{P}$ & $\mathrm{I} \& \mathrm{P}$ \\
\hline IN & $\mathrm{P}$ & $\mathrm{P}$ & $\mathrm{P}$ & $\mathrm{P}$ & $\mathrm{P}$ & $\mathrm{P}$ & $\mathrm{P}$ & $P$ & $\mathrm{P}$ & SD & $\sim$ & $\mathrm{I}$ & I & $\mathrm{I}$ & I & I & I & $\mathrm{I}$ & $\mathrm{I}$ \\
\hline KS & $\mathrm{I} \& \mathrm{P}$ & $\mathrm{I} \& \mathrm{P}$ & $\mathrm{I} \& \mathrm{P}$ & $\mathrm{I} \& \mathrm{P}$ & $\mathrm{I} \& \mathrm{P}$ & $\mathrm{I} \& \mathrm{P}$ & $\mathrm{I} \& \mathrm{P}$ & $\mathrm{I} \& \mathrm{P}$ & $\mathrm{I} \& \mathrm{P}$ & $\mathrm{TN}$ & $\sim$ & $\sim$ & $\sim$ & $\sim$ & $\sim$ & $\sim$ & $\sim$ & $\sim$ & $\sim$ \\
\hline $\mathrm{KY}$ & I\&P & $\mathrm{I} \& \mathrm{P}$ & $\mathrm{I} \& \mathrm{P}$ & $\mathrm{I} \& \mathrm{P}$ & $\mathrm{I} \& \mathrm{P}$ & $\mathrm{I} \& \mathrm{P}$ & $\mathrm{I} \& \mathrm{P}$ & $\mathrm{I} \& \mathrm{P}$ & $\mathrm{I} \& \mathrm{P}$ & $\mathrm{TX}$ & $\mathrm{I} \& \mathrm{P}$ & $\mathrm{I} \& \mathrm{P}$ & $\mathrm{I} \& \mathrm{P}$ & $\mathrm{I} \& \mathrm{P}$ & $\mathrm{I} \& \mathrm{P}$ & I\&P & I\&P & $\mathrm{I} \& \mathrm{P}$ & $\mathrm{I} \& \mathrm{P}$ \\
\hline LA & $\sim$ & $\sim$ & $\sim$ & $\sim$ & $\sim$ & $\sim$ & $\sim$ & $\sim$ & $\sim$ & UT & I\&P & I\&P & I\&P & I\&P & $\mathrm{I} \& \mathrm{P}$ & I\&P & I\&P & I\&P & $\mathrm{I} \& \mathrm{P}$ \\
\hline MA & $\sim$ & $\sim$ & $\sim$ & $\sim$ & $\sim$ & $\sim$ & $\sim$ & $\sim$ & $\sim$ & VA & $\mathrm{I} \& \mathrm{P}$ & I\&P & I\&P & I\&P & $\mathrm{I} \& \mathrm{P}$ & I\&P & I\&P & I\&P & I\&P \\
\hline MD & $\sim$ & $\sim$ & $\sim$ & $\sim$ & $\sim$ & $\sim$ & $\sim$ & $\sim$ & $\sim$ & VT & $\sim$ & $\sim$ & $\sim$ & $\sim$ & $\sim$ & $\sim$ & $\sim$ & $\sim$ & $\sim$ \\
\hline $\mathrm{ME}$ & $\sim$ & $\sim$ & $\sim$ & $\sim$ & $\sim$ & $\sim$ & $\sim$ & $\sim$ & $\sim$ & WA & $\sim$ & $\sim$ & $\sim$ & $\sim$ & $\sim$ & $\sim$ & $\sim$ & $\sim$ & $\sim$ \\
\hline MI & $\sim$ & $\mathrm{I} \& \mathrm{P}$ & $\mathrm{I} \& \mathrm{P}$ & $\mathrm{I} \& \mathrm{P}$ & $\mathrm{I} \& \mathrm{P}$ & $\mathrm{I} \& \mathrm{P}$ & $\mathrm{I} \& \mathrm{P}$ & $\mathrm{I} \& \mathrm{P}$ & $\mathrm{I} \& \mathrm{P}$ & WI & $\sim$ & $\sim$ & $\sim$ & $\sim$ & $\sim$ & $\sim$ & $\sim$ & $\sim$ & $\sim$ \\
\hline MN & I\&P & $\mathrm{I} \& \mathrm{P}$ & I\&P & $\mathrm{I} \& \mathrm{P}$ & I\&P & $\sim$ & $\sim$ & $\sim$ & $\sim$ & WV & $\sim$ & $\sim$ & $\sim$ & $\sim$ & $\sim$ & $\sim$ & $\sim$ & $\sim$ & $\sim$ \\
\hline $\mathrm{MO}$ & $\sim$ & $\sim$ & $\sim$ & $\sim$ & $\sim$ & $\sim$ & $\sim$ & $\sim$ & $\sim$ & WY & $I \& P$ & $\mathrm{I} \& \mathrm{P}$ & $\mathrm{I} \& \mathrm{P}$ & $\mathrm{I} \& \mathrm{P}$ & $\mathrm{I} \& \mathrm{P}$ & $\mathrm{I} \& \mathrm{P}$ & $\mathrm{I} \& \mathrm{P}$ & $\mathrm{I} \& \mathrm{P}$ & I\&P \\
\hline MS & $\mathrm{P}$ & $\mathrm{P}$ & $\mathrm{P}$ & $\mathrm{P}$ & $\mathrm{P}$ & $\mathrm{P}$ & $\mathrm{P}$ & $\mathrm{P}$ & $\mathrm{P}$ & & & & & & & & & & \\
\hline
\end{tabular}

This table illustrates which states have provided statutory immunity (“I”), statutory audit privilege (“P”), both ("I\&P”), or neither during our sample period. Sources include Morandi (1998), US EPA’s Audit Policy website (http://www.epa.gov/region5/orc/audits/audit_apil.htm), and a private web service run by the Auditing Roundtable (http://www.auditing-roundtable.org). We resolved any inconsistencies by referring to the actual statutory language in LEXIS-NEXIS state statutory databases. 
TABLE A-3

\section{FEDERAL CIRCUIT COURT IDEOLOGY}

Proportion of judges on each Circuit that were nominated by a Democratic President, average during 1990-1994

\begin{tabular}{cc}
\hline US Circuit Court & \\
\hline 1 & $12.5 \%$ \\
2 & $38.9 \%$ \\
3 & $26.7 \%$ \\
4 & $37.5 \%$ \\
5 & $36.4 \%$ \\
6 & $35.3 \%$ \\
7 & $16.7 \%$ \\
8 & $30.8 \%$ \\
9 & $46.7 \%$ \\
10 & $41.7 \%$ \\
11 & $46.2 \%$ \\
DC & $42.9 \%$ \\
\hline
\end{tabular}

Source: Based on data from Zuk, Barrow \& Gryski (1996) 
Page: 18

LATER:

brand prominence: We measure brand prominence as a dummy variable coded 1 for facilities that are affiliated with any of Business Week’s “Top 100 Brands” lists during 2001-2004 (Business Week 2001; 2002; 2003; 2004). We identified all corporate affiliates of these brands using the Directory of Corporate Affiliations database via LexisNexis.

Business Week (2001) “The 101 Top Brands,” 6 Aug., p. 60.

Business Week (2002) “The 100 Top Brands,” 5 Aug., p. 95.

Business Week (2003) “The 100 Top Brands,” 5Aug., p. 72.

Business Week (2004) “The 100 Top Brands” 2 Aug., p. 64.

Corporate affiliate of a top 100 brand Dummy coded 1 if the facility is in the corporate family of a Business Week “Top 100 Brand” in any year during 2001-2004 